Ritrýnd grein birt 10. september 2021

\title{
Pekking og aðferðir grunnskólakennara á Íslandi í stuðningi við nemendur með ADHD
}

\author{
Bergljót Gyða Guðmundsdóttir, Erla Karlsdóttir og Margrét Sigmarsdóttir \\ Abstract $\backslash$ Um höfunda About the authors $>$ Heimildir
}

\begin{abstract}
Árangursríkar forvarnir og stuðningur fyrir börn og ungmenni með taugaproskaraskanir, svo sem athyglisbrest með/án ofvirkni/hvatvísi (ADHD), eru nauðsynleg til að styðja við farsælan proska peirra. Starfsfólk skóla gegnir gjarnan lykilhlutverki við að veita pann stuðning og er pví mikilvægt að pað hafi tækifæri, pekkingu og færni til að sinna honum á besta mögulega hátt. Markmið pessarar rannsóknar var að meta hvaðan pekking starfandi grunnskólakennara á Íslandi sem kenndu að lágmarki einum nemanda með frum- eða staðfesta greiningu á ADHD um röskunina kæmi, hversu vel undirbúnir peir teldu sig vera fyrir kennslu pessa nemendahóps, áherslur peirra og aðferðir við stuðning pessara nemenda og fleira. Öllum meðlimum í Félagi grunnskólakennara var sendur tölvupóstur með boði um pátttöku í rafrænni könnun og úrtak pessarar rannsóknar samanstóð af $\mathrm{N}=592$ grunnskólakennurum sem uppfylltu fyrrgreind pátttökuskilyrði (svarhlutfall 13\%). Niðurstöður sýndu að flestir pátttakendur (91\%) byggðu pekkingu sína um ADHD á reynslu af kennslu nemenda með röskunina sem er í samræmi við niðurstöður fyrri rannsókna. Marktæk tengsl komu fram milli ýmissa svara pátttakenda og starfsaldurs peirra. Meðal annars kom í ljós að fleiri kennarar með styttri starfsaldur (60-66\%) sögðust sækja pekkingu á ADHD til náms síns en kennarar sem starfað höfðu lengur (29-44\%). Meirihluti pátttakenda sagðist beita einhverjum peirra aðferða sem teljast árangursríkar í stuðningi við nemendur með ADHD og virtust peir einnig hafa nokkra pekkingu á gagnreyndum úrræðum. Niðurstöður bentu jafnframt til pess að kennarar gætu haft gagn af starfspróun á pessu sviði, sérstaklega ráðgjöf og handleiðslu í gagnreyndum aðferðum við stuðning og mat á árangri innan skóla fyrir nemendur með ADHD. Farið er yfir helstu takmarkanir rannsóknarinnar og tillögur settar fram um næstu skref í rannsóknum á pessu efni.
\end{abstract}

Efnisorð: ADHD, athyglisbrestur með ofvirkni/hvatvísi, grunnskólakennarar, gagnreyndar aðferðir, stuðningur við nemendur

\section{Inngangur}

Tækifæri skólasamfélagsins til að hafa jákvæð áhrif á proska og framtîðarhorfur nemenda eru ótalmörg og starfsfólk skóla gegnir veigamiklu hlutverki í stuðningi við nám, hegðun og líðan allra barna og ungmenna. Petta á ekki síst við um nemendur sem purfa aukinn stuðning, til dæmis pá sem greindir hafa verið með taugaproskaröskun eins og til dæmis athyglisbrest með/án ofvirkni/ hvatvísi (e. attention-deficit hyperactivity disorder; ADHD). ADHD einkennist fyrst og fremst af einbeitingarerfiðleikum og/eða ofvirkni/hvatvísi sem purfa að hafa komið fram fyrir 12 ára aldur og trufla viðkomandi í athöfnum daglegs lífs, svo sem í námi, starfi og félagslegum samskiptum (American Psychiatric Association, 2013). Samantekt 175 rannsókna sem fram fóru víða um heim 
benti til pess að allt að um 8\% barna uppfylli greiningarviðmið fyrir ADHD (Thomas o.fl., 2015). Miðað við pær tölur má áætla að í hverjum bekk 20 grunnskólanema séu að jafnaði einn til tveir nemendur sem gætu greinst með ADHD, pannig að á starfsferli sínum koma flestir kennarar að kennslu pessara nemenda.

Fjöldi rannsókna hefur sýnt að horfur nemenda með ADHD, bæði í barnæsku og á fullorðinsárum, eru almennt lakari en peirra sem ekki eru greindir með röskunina, til dæmis hvað varðar námsástundun, námsárangur, hegðunarvanda (DuPaul og Langberg, 2014), geðheilsu, einkum punglyndi og kvíða (Anastopoulos o.fl., 2018), áfengis- og vímuefnaneyslu (Molina o.fl., 2018), áhættuhegðun í kynlífi (Sarver o.fl., 2014), erfiðleika í félagslegum samskiptum (Kofler o.fl., 2018), stöðu á vinnumarkaði (Kuriyan o.fl., 2013), umferðaróhöpp og -lagabrot (Curry o.fl., 2019) og slysatíðni (Barkley, 2014). Truflun af völdum einkenna röskunarinnar virðist jafnvel enn eiga við um ungmenni sem greind voru með ADHD snemma í æsku en uppfylla ekki lengur greiningarviðmið (Lee o.fl., 2008).

Mikilvægi árangursríkra forvarna og stuðnings fyrir börn, ungmenni og fullorðna með pessi einkenni, hvort sem pau mæta greiningarviðmiðum eða ekki, er pví óumdeilanlegt. Kennarar gegna par mikilvægu hlutverki og pessi rannsókn varpar ljósi á pekkingu og áherslur kennara við að veita pennan stuðning.

\section{Meðferð og stuðningur við hegðun og nám nemenda með ADHD}

Helstu gagnreyndu meðferðarúrræði (e. evidence-based interventions) við ADHD hjá börnum og ungmennum eru annars vegar pjálfun í uppeldisfærni með áherslu á atferlismótandi aðferðir (Evans o.fl., 2018) og hins vegar lyfjameðferð fyrir börn sex ára og eldri (Wolraich o.fl., 2019) en lyfjameðferð er almennt talin örugg og áhrifarík við að draga úr einkennum ADHD meðal barna og ungmenna (Catalá-López o.fl., 2017; Connor, 2014; Cortese o.fl., 2018). Auk pess hafa niðurstöður rannsókna sýnt að markviss stuðningur við foreldra/uppalendur barna með ADHD hefur margvísleg jákvæð áhrif (Bjørnebekk o.fl., 2015; Patterson o.fl., 2010; Rains o.fl., 2021) og getur dregið úr alvarleika ýmissa algengra fylgikvilla ásamt einkennum mótpróa- og/eða hegðunarraskana (Chronis o.fl., 2004). Sýnt pykir pó að meðferðarúrræði sem efla foreldrafærni byggjast á sterkari rannsóknagrunni en nokkur önnur meðferðarnálgun fyrir hegðunarerfiðleika barna á leik- og grunnskólaaldri (Kazdin, 2005). Árangur næst sérstaklega samhliða lyfjameðferð (Catalá-López o.fl., 2017) og sumar rannsóknir sýna meiri árangur hjá foreldrum yngri barna (Evans o.fl., 2018). Prátt fyrir gagnsemi árangursríkrar uppeldisráðgjafar vegna ADHD, og í sumum tilvikum einnig lyfjameðferðar, er ekki hægt að gera ráð fyrir að öll börn og fjölskyldur peirra hafi aðgang að slíkri ráðgjöf eða vilji nýta sér lyfjameðferð. Hins vegar ganga flest barnanna í skóla par sem finna má fjölda tækifæra til að styðja við farsælan proska peirra samhliða pví að veita foreldrum aðgang að gagnreyndum foreldrafærniúrræðum. Vísir að sampættri stuðningspjónustu innan skóla og til fjölskyldna er til hér á landi (Margrét Sigmarsdóttir og Anna Björnsdóttir, 2012).

Töluvert er um gagnreynd skólaúrræði fyrir nemendur með ADHD en í samantekt DuPaul og félaga (2012) á niðurstöðum 60 rannsókna kom í ljós að ýmis úrræði byggð á aðferðum hagnýtrar atferlisgreiningar, markvissum stuðningi við nám og aðferðum hugrænnar atferlismeðferðar höfðu mikil eða miðlungsmikil jákvæð áhrif á nám og hegðun nemenda með pennan vanda. Ályktað var að markviss stuðningur í skóla ætti að vera fyrsta úrræði (e. first-line treatment) fyrir pessa nemendur (DuPaul o.fl., 2012). Klínískar leiðbeiningar frá Embætti landlæknis (Gísli Baldursson o.fl., 2012) um vinnulag við greiningu og meðferð ADHD byggjast á sama fræðagrunni varðandi stuðning innan skóla. Aðferðir sem beinast að aðdraganda og afleiðingum hegðunar, til dæmis að útbúa skýrt og styðjandi námsumhverfi og veita skýr fyrirmæli, ásamt markvissri hvatningu, eru áhrifaríkar fyrir nemendur með ADHD (DuPaul o.fl., 2012). Að auki voru aðferðir sem efla sjálfstjórn og kenna nemendum að skrá og fylgjast með eigin hegðun taldar árangursríkar. Norrænar rannsóknir á hliðstæðum aðferðum (t.d. Sørlie og Ogden, 2015) hafa jafnframt sýnt jákvæð áhrif á hegðun og námsástundun nemenda með pennan vanda. Íslenskar rannsóknir styðja einnig við gagnsemi aðferðanna hérlendis (Guðrún Björg Ragnarsdóttir og Anna-Lind Pétursdóttir, 2013) og hafa sýnt að pær höfði vel til nemenda, að peirra eigin mati (Sesselja Ârnadóttir og Anna-Lind Pétursdóttir, 2013). Markviss bekkjarstjórnun kennara sem einkennist af styðjandi aðferðum 
og sterkum tengslum kennara við nemendur stuðlar að aukinni sjálfstjórn, námsástundun, jákvæðri hegðun (Bowman-Perrott o.fl., 2016; Kellam o.fl., 2011) og bættri líðan (Korpershoek o.fl., 2016), ekki síst nemenda með ADHD og/eða hegðunarvanda (Evans o.fl., 2014). Í pessu samhengi er grundvallaratriði að starfsfólk skóla hafi pekkingu, færni og starfsprek til að sinna bekkjarstjórnun og auknum stuðningi við nemendur sem á honum purfa að halda, á besta mögulega hátt.

\section{Pekking og færni kennara í stuðningi við nemendur með ADHD og hegðunar- vanda}

Rannsóknum ber saman um mikilvægi pess að kennarar pekki árangursrík stuðningsúrræði fyrir nemendur með ADHD (Sherman o.fl., 2008). Pekking dugir pó ekki til ein og sér heldur parf að nýta aðferðirnar rétt og markvisst í öllu skólastarfi og pann pátt er mikilvægt að styrkja (Arcia o.fl., 2000; Murray o.fl., 2011) par sem bil er milli fræðipekkingar og hagnýtingar hennar á vettvangi skóla (Dort o.fl., 2020; DuPaul o.fl., 2020). Erlendar rannsóknir benda almennt til pess að kennara og kennaranema skorti pekkingu á röskuninni (Anderson o.fl., 2012; Bekle, 2004; Jerome o.fl., 1994; Kos o.fl., 2004; Mulholland o.fl., 2015; Poznanski o.fl., 2018), meðal annars á viðurkenndum stuðningsúrræðum vegna ADHD sem nýta mætti innan skólaumhverfisins (Anderson o.fl., 2012). Niðurstöður viðamikillar rannsóknar á stuðningi í skóla við 2495 börn og ungmenni með ADHD á aldrinum 4-17 ára í Bandaríkjunum renndu stoðum undir petta par sem fram kom að aðeins $32 \%$ nemenda úr pessum hópi nutu stuðnings við hegðun inni í bekk og að um $20 \%$ peirra hlutu engan stuðning í skóla prátt fyrir mikla truflun af völdum einkenna í námi og félagslegum samskiptum (DuPaul o.fl., 2019). Rannsókn Hart og félaga (2017) meðal kennara nemenda á síðasta ári í leikskóla til 8. bekkjar víðs vegar um Bandaríkin sýndi að kennarar yngri nemenda (leikskóla - 2 . bekkjar) nýttu marktækt fleiri stuðningsaðferðir við kennslu barna með ADHD en kennarar eldri nemenda, pannig að eldri nemendur með röskunina nutu sîður stuðnings en yngri nemendur. Petta er áhyggjuefni enda undirstrikuðu niðurstöður nýlegrar rannsóknar DuPaul og félaga (2021) mikilvægi stuðnings við nám ungmenna með ADHD í framhaldsskóla (e. high school) par sem hann spáði fyrir um námsgengi í grunnnámi í háskóla. Eins sýndu niðurstöður stórrar langtímarannsóknar meðal barna og ungmenna með ADHD að prátt fyrir að rúmur helmingur pátttakendahópsins hlyti sérstakan stuðning við nám í framhaldsskóla byggðist minna en fjórðungur pess stuðnings á gagnreyndum aðferðum (Murray o.fl., 2014). Fræðipekking um bestu mögulegu stuðningsaðferðir fyrir nemendur með ADHD virðist pví ekki skila sér nægilega vel til starfandi kennara.

Nokkrar íslenskar rannsóknir á pekkingu, viðhorfum og reynslu grunnskólakennara af kennslu nemenda með ADHD og/eða hegðunarvanda hafa einnig farið fram. Í rannsókn Jónínu Sæmundsdóttur (2009) meðal 122 kennara á Íslandi kom til dæmis fram að prátt fyrir að meirihluti pátttakenda teldi sig hafa að minnsta kosti frekar góða pekkingu á ADHD voru aðeins $6 \%$ sammála pví að nám peirra hefði búið pá nægilega vel undir kennslu nemenda með $\mathrm{ADHD}$ en að sú pekking sem peir byggju yfir kæmi oftast til einmitt vegna reynslu af kennslu pessa nemendahóps. Rúmur helmingur pátttakenda sótti stuðning/ráðgööf til sérkennara vegna kennslu nemenda með ADHD, tæpur priðjungur til skólasálfræðings og um 15\% til námsráðgjafa. Pá kom í ljós að meirihluti pátttakenda taldi flæði upplýsinga meðal starfsfólks skólans um nemendur með ADHD ófullnægjandi (Jónína Sæmundsdóttir, 2009).

Rannsókn Snæfríðar Drafnar Björgvinsdóttur og Önnu-Lindar Pétursdóttur (2014) á umfangi og afleiðingum hegðunarvanda nemenda meðal 95 starfandi grunnskólakennara á höfuðborgarsvæðinu benti til pess að peir fengju helst stuðning til að takast á við erfiða hegðun nemenda, svo sem truflun, mótpróa eða óhlýðni sem eru algengir fylgifiskar ADHD (Danforth o.fl., 2016; Urður Njarðvík, 2017), frá samkennurum eða stuðningsfulltrúum, stjórnendum skóla og/eða foreldrum. Einnig kom fram í meistararitgerð Snæfríðar Drafnar Björgvinsdóttur (2014), sem fyrrnefnd rannsókn Snæfríðar Drafnar og Önnu-Lindar (2014) byggðist á, að grunnskólakennarar sem tóku pátt töldu kennaranám sitt ekki hafa veitt nægjanlega pjálfun eða pekkingu til pess að takast á við krefjandi hegðun nemenda en að færni peirra á pessu sviði hefði pó aukist samhliða lengri starfsreynslu. Að mati sama 
pátttakendahóps var erfið hegðun nemenda nánast daglegt brauð, hún hefði mikil neikvæð áhrif á bæði kennara og nemendur, ýtti meðal annars undir streitu og drægi úr afköstum í starfi kennara, að pví marki að rúmur helmingur pátttakenda sagðist hafa íhugað að hætta kennslustörfum af pessum sökum (Snæfríður Dröfn Björgvinsdóttir og Anna-Lind Pétursdóttir, 2014).

Svipaðar niðurstöður komu fram í könnun Sambands íslenskra sveitarfélaga (SÍS) og Félags grunnskólakennara (FG) (2012) meðal starfandi kennara par sem meirihluti peirra sem tóku pátt taldi hegðunarvanda meðal nemenda hafa ýtt verulega undir álag í starfi. Pótt hvorki rannsókn Snæfríðar Drafnar Björgvinsdóttur og Önnu-Lindar Pétursdóttur (2014) né könnun SÍS og FG (2012) hafi beinst sérstaklega að kennslu nemenda með ADHD er sennilegt að allavega einhvern hluta pess hegðunarvanda sem pátttakendur greindu frá og áhrif hans á kennara og nemendur megi rekja til ADHD, vegna fyrrnefndrar skörunar milli pessarar röskunar og hegðunarvanda (Danforth o.fl., 2016; Urður Njarðvík, 2017).

Mikilvægt er að starfsfólk skóla kunni og geti nýtt pær aðferðir sem eru árangursríkastar til að styðja við hegðun og líðan nemenda. Færni og trú kennara á eigin getu, til dæmis til að takast á við hegðun nemenda, tengjast líðan kennara, svo sem kulnunareinkennum (Dicke o.fl., 2014), en kulnunareinkenni kennara tengjast einnig meiri hegðunarvanda, lakari námsframmistöðu og minni áhugahvöt nemenda (Madigan og Kim, 2021). Meistararannsókn Erlu Karlsdóttur (2019) varpaði ljósi á kulnunareinkenni meðal íslenskra grunnskólakennara nemenda með ADHD, en sú rannsókn sem hér er fjallað um byggist á gögnum sem safnað var í meistaraverkefni hennar. Til dæmis tengdist notkun fleiri sannreyndra aðferða við kennslu nemenda með ADHD marktækt hærra mati pátttakenda á eigin starfsárangri (e. personal achievement) á spurningalista Maslach og Jackson (1981) um kulnun í starfi (Erla Karlsdóttir, 2019). Niðurstöður áðurnefndra rannsókna gefa tilefni til að rýna betur í pekkingu kennara og pær aðferðir sem peir nýta við kennslu nemenda með ADHD, par sem líklegt er að pessir pættir hafi áhrif á hegðun, námsframmistöðu og líðan nemenda ásamt líðan kennaranna sjálfra.

\section{Markmið rannsóknar}

Rúmur áratugur er liðinn síðan Jónína Sæmundsdóttir (2009) greindi frá niðurstöðum rannsóknar sinnar á pekkingu og reynslu kennara af kennslu nemenda með ADHD. Íslenskar rannsóknir sem birst hafa síðan pá benda til pess að álag á kennara vegna hegðunarvanda hafi aukist (SÍS og FG, 2012; Snæfríður Dröfn Björgvinsdóttir og Anna-Lind Pétursdóttir, 2014). Sennilegt er að ADHD-einkenni nemenda og viðbrögð kennara við peim hafi par áhrif (Erla Karlsdóttir, 2019). Par sem samsláttur milli hegðunarvanda og ADHD er mikill er brýnt að kanna sérstaklega pekkingu og reynslu kennara af kennslu nemenda með ADHD, ánægju kennara með veittan stuðning við kennslu pessa nemendahóps og hvað hindrar kennara í árangursríkri kennslu nemenda með röskunina, svipað og í rannsókn Jónínu Sæmundsdóttur (2009), og hvort eitthvað hefur breyst miðað við niðurstöður hennar. Par að auki er gagnlegt að kanna hversu vel íslenskir kennarar pekkja viðurkenndar aðferðir í stuðningi við nemendur með ADHD, hvort og pá hvernig kennarar mæla breytingar í hegðun nemenda sinna, með hvaða aðferðum kennarar mæla í tengslum við ADHD, og hvort munur sé á hópum kennara á pessum páttum eftir starfsaldri, par sem kennarar telja reynslu sína af kennslu nemenda með ADHD eina helstu uppsprettu pekkingar sinnar um röskunina (Jónína Sæmundsdóttir, 2009). Markmið pessarar rannsóknar var pví að svara eftirfarandi spurningum, með hliðsjón af starfsreynslu og skólastigi kennara og setja svör pátttakenda í samhengi við fræðipekkingu um viðurkennt verklag við stuðning í skólum við nemendur með ADHD:

- Hvert sækja íslenskir grunnskólakennarar helst pekkingu sína um ADHD?

- Hversu vel telja íslenskir grunnskólakennarar að nám peirra hafi búið pá undir kennslu nemenda með ADHD?

- Hverjar eru helstu aðferðir og áherslur íslenskra grunnskólakennara í stuðningi við nemendur með ADHD? 


\section{Аðferð}

\section{Pátttakendur}

Öllum meðlimum í Félagi grunnskólakennara (FG) var boðið að taka pátt í rannsókninni og svöruðu 633 pátttakendur könnuninni sem samsvarar um 13\% pátttökuhlutfalli, miðað við að heildarfjöldi félaga í FG á pessum tíma var um 5000. Úrtak pessarar rannsóknar samanstóð af $N=592$ kennurum $(88,5 \%$ konur, 9,6\% karlar, 1,9\% annað/upplýsingar vantaði) sem sögðust kenna að minnsta kosti einum nemanda með frum- eða staðfesta greiningu á ADHD. Meðalaldur pátttakenda var 48,4 ár $(s f=9,8)$ og starfsaldur peirra á bilinu 1 - 45 ár ( $m=16,7$ ár, $s f=10,1$ ár). Um 52\% pátttakenda greindu frá pví að hæsta stig menntunar sem peir hefðu lokið væri B.Ed.-gráða $(n=309)$, næstflestir $(n=145)$, eða tæp 25\%, höfðu lokið M.Ed.-gráðu. Tæp 20\% pátttakenda $(n=120)$ höfðu lokið annarri háskólamenntun og/eða aflað sér kennsluréttinda. Dreifing pátttakenda milli grunnskólastiganna priggja var nokkurn veginn jöfn en 33,3\% pátttakenda sögðust kenna mest á yngsta stigi, 32,3\% á miðstigi og 32,1\% á unglingastigi. Rúmur helmingur pátttakenda $(n=324)$, eða um 55\%, sagðist starfa á höfuðborgarsvæðinu en tæp 44\% pátttakenda $(n=259)$ sögðust starfa á landsbyggðinni.

\section{Mælivgar}

Pátttakendur voru spurðir um pekkingu sína á meðferð/stuðningi við nemendur með ADHD og reynslu af stuðningi við kennslu nemenda með ADHD, ásamt spurningum um ýmsa bakgrunnspætti (svo sem kyn, lífaldur, starfsaldur, menntun og fleira). Allar spurningar voru forprófaðar af fimm manneskjum með háskólamenntun á sviði mennta-, heilbrigðis- og/eða félagsvísinda, sem valdar voru af hentugleika. Að forprófun lokinni gerðu höfundar smávægilegar breytingar á orðalagi, svarmöguleikum og framsetningu spurninga, með hliðsjón af athugasemdum peirra sem tóku pátt í forprófun.

Undirbúningur kennara og reynsla af kennslu nemenda með ADHD. Pátttakendur voru spurðir sjö spurninga um undirbúning sinn og reynslu af kennslu nemenda með ADHD, auk spurninga um upplifun sína af stuðningi við kennslu pessa nemendahóps. Hluti spurninga var saminn af höfundum en aðrar spurningar komu úr rannsókn Jónínu Sæmundsdóttur (2009) sem sótti hluta spurninga sinna til Reid og félaga (1994). Við sumum spurningum voru pátttakendur beðnir um að merkja við öll atriði á lista sem ættu við um pá (p.e. „Hvaðan er pekking pín um ADHD fengin?“, Hvaða starfsfólk hefur veitt pér stuðning/ráðgjöf við kennslu barna með ADHD?“ og „Hvað hindrar pig helst við árangursríka kennslu nemenda með ADHD?“). Öðrum spurningum var svarað á fimm punkta Likert-kvarða (t.d. „mjög sammála - frekar sammála - hvorki/né - frekar ósammála - mjög ósammála“), auk svarmöguleikanna „veit ekki“ eða „vil ekki svara“ (p.e. um undirbúning vegna kennslu barna með ADHD að námi loknu, flæði upplýsinga milli starfsfólks skólans um nemendur með ADHD, hversu vel pátttakendur teldu sig sinna nemendum með ADHD og ánægju/óánægju peirra með veittan stuðning við kennslu nemenda með ADHD).

Dekking kennara á stuðningi við nemendur með ADHD. Höfundar settu saman fimm spurningar um pekkingu kennara á stuðningi við nemendur með ADHD í skóla, sem byggðust á og fjölluðu um klínískar leiðbeiningar Embættis landlæknis um greiningu og meðferð ADHD (Gísli Baldursson o.fl., 2012) og um hagnýta atferlisgreiningu. Í premur spurningum voru pátttakendur beðnir um að merkja við öll atriði á lista sem ættu við um pá (p.e. um stuðningsaðferðir við kennslu nemenda með ADHD, mæliaðferðir til að meta árangur af stuðningi við nemendur með ADHD og aðferðir sem pátttakendur mæltu með við aðra vegna nemenda með ADHD) en tveimur spurningum var svarað á fimm punkta Likert-kvarða (t.d. „mjög vel - frekar vel - hvorki/né - frekar illa - mjög illa“), auk svarmöguleikanna „veit ekki“ eða „vil ekki svara“ (p.e. „Hversu vel eða illa pekkir pú aðferðir hagnýtrar atferlisgreiningar?“ og „Hversu vel eða illa pekkir pú klínískar leiðbeiningar Embættis landlæknis um vinnulag við greiningu og meðferð ADHD?“).

Bakgrunnsspurningar. Pátttakendur voru beðnir um að svara spurningum sem samdar voru af höfundum um kyn, lífaldur, hæsta stig menntunar sem peir hefðu lokið, starfsaldur við grunnskólakennslu, stig kennslu (yngsta, mið- eða unglingastig), starfshlutfall og landsvæði. 


\section{Framkvæmd}

Rannsóknin var sampykkt af Vísindasiðanefnd (tilvísun: VSN-19-070). Stutt kynning á rannsókninni og boð um pátttöku var sent í tölvupósti til allra meðlima í Félagi grunnskólakennara í apríl 2019, ásamt ítrekunarpósti í maí 2019. Væntanlegum pátttakendum var greint frá tilgangi rannsóknar og mögulegum ávinningi hennar, pað er aukinni pekkingu á starfsháttum og -umhverfi kennara með sérstakri áherslu á kennslu nemenda með ADHD. Væntanlegir pátttakendur gátu svo smellt á tengil í tölvupóstinum sem beindi peim á nafnlausa, rafræna könnun á Google Forms, par sem peir gátu hafist handa við að svara fyrrgreindum spurningalistum og par með veitt sampykki sitt (nafnlaust) fyrir pátttöku. Pátttakendum var gert ljóst að pátttaka væri algjörlega valfrjáls, peir mættu hafna pátttöku í rannsókninni og ef peir tækju pátt mættu peir hætta pátttöku hvenær sem væri. Pátttakendum var greint frá pví að ef peir fyndu fyrir einhverri vanlíðan í kjölfar pátttöku í rannsókninni byðist peim viðtal við sjálfstætt starfandi sálfræðing sem var óháður rannsókninni, sér að kostnaðarlausu. Pátttakendur gátu haft samband við sálfræðinginn milliliðalaust í gegnum síma og/eða tölvupóst, ef við átti.

\section{Úrvinnsla gagna}

Unnið var úr gögnum í Microsoft Excel og IBM SPSS Statistics 26. Rannsóknin var með pversniði (e. cross-sectional design) og voru gögn greind með samanburði milli hópa pátttakenda eftir starfsaldri og skólastigi og með lýsandi tölfræði. Hópasamanburður fór fram með kí-kvaðratprófum og eftirásamanburði með z-prófum, auk dreifigreiningar og eftirásamanburðar með t-prófum og Bonferroni-leiðréttingu. Hlutfall upplýsinga sem vantaði (e. missing data) var á bilinu 0,0-6,4\%.

\section{Niðurstöður}

\section{Kennsla nemenda með ADHD}

Svör við spurningum voru könnuð eftir starfsaldri og skólastigi (yngsta, mið- og unglingastig) pátttakenda. Par sem aðeins fimm pátttakendur voru í hópnum með meira en 40 ára starfsreynslu var sá hópur sameinaður hópi pátttakenda með 31-40 ára starfsreynslu, til pess að auðvelda samanburð við hópa pátttakenda með 1-10 ára reynslu, 11-20 ára reynslu og 21-30 ára reynslu.

Svör pátttakenda um undirbúning fyrir kennslu nemenda með ADHD sýndu að rúmur helmingur pátttakenda (51\%) taldi sig „frekar illa“ eða „mjög illa“ undir hana búinn en 19\% töldu að námið hefði búið sig „frekar vel“ eða „mjög vel“ undir petta hlutverk. Niðurstöður kí-kvaðratprófs sýndu að marktæk tengsl voru milli starfsaldurs og mats á undirbúningi úr námi fyrir kennslu nemenda með $\operatorname{ADHD~X}^{2}(12, N=576) 22,08, p=0,037$. Eftirápróf leiddu í ljós að marktækt lægra hlutfall í hópi pátttakenda með 1-10 ára starfsreynslu (15\%) merkti við að kennaranám hefði búið pá „mjög illa“ undir kennslu nemenda með ADHD heldur en í hópum pátttakenda með 21-30 ára (30\%) starfsaldur.

\section{Uppruni pekkingar um ADHD}

Algengast var að pátttakendur segðu að pekking peirra á ADHD ætti rætur sínar að rekja til kennslu nemenda með röskunina (91\%), par á eftir komu fyrirlestrar (80\%), námskeið (69\%), netið (65\%) og svo bækur (61\%). Kennaranám var par á eftir í 6. sæti en rúmur helmingur (55\%) pátttakenda sagðist hafa hlotið pekkingu sína paðan (sjá nánar í Töflu 1). Niðurstöður kí-kvaðratprófs sýndu að marktæk tengsl voru á milli starfsaldurs og mats á uppruna pekkingar á ADHD par sem kennarar með styttri starfsaldur töldu sig frekar sækja pekkingu sína til kennaranámsins. Í Töflu 1 má sjá ýtarlegri niðurstöður eftir starfsaldurshópum kennara. 
Tafla 1. Samanburður á fjölda og hlutfalli pátttakenda sem merktu við mismunandi uppruna pekkingar um ADHD eftir starfsreynsluhópum.

Hópar pátttakenda eftir starfsreynslu (í árum)

\begin{tabular}{|c|c|c|c|c|c|c|}
\hline & \\
\hline & $\begin{array}{l}\text { Heild } \\
n(\%)\end{array}$ & $\begin{array}{l}1-10 \\
n(\%)\end{array}$ & $\begin{array}{l}11-20 \\
n(\%)\end{array}$ & $\begin{array}{l}21-30 \\
n(\%)\end{array}$ & $\begin{array}{c}31+ \\
n(\%)\end{array}$ & $\begin{array}{l}\text { Niðurstöður kí-kvaðratprófs } \\
\text { á tengslum milli breyta }\end{array}$ \\
\hline $\begin{array}{l}\text { Að kenna barni } \\
\text { með ADHD }\end{array}$ & $\begin{array}{l}537 \\
(91)\end{array}$ & $\begin{array}{c}158 \\
(88)^{\mathrm{a}}\end{array}$ & $\begin{array}{l}206 \\
(90)^{\mathrm{a}}\end{array}$ & $\begin{array}{c}112 \\
(96)^{\mathrm{a}}\end{array}$ & $\begin{array}{c}58 \\
(89)^{\mathrm{a}}\end{array}$ & $p=0,18$ \\
\hline Fyrirlestri/-um & $\begin{array}{l}475 \\
(80)\end{array}$ & $\begin{array}{l}126 \\
(70)^{\mathrm{a}}\end{array}$ & $\begin{array}{l}193 \\
(85)^{\mathrm{b}}\end{array}$ & $\begin{array}{l}100 \\
(86)^{\mathrm{b}}\end{array}$ & $\begin{array}{c}54 \\
(83)^{a, b}\end{array}$ & $p=0,001$ \\
\hline Námskeiði/-um & $\begin{array}{l}409 \\
(69)\end{array}$ & $\begin{array}{c}91 \\
(51)^{\mathrm{a}}\end{array}$ & $\begin{array}{l}176 \\
(77)^{\mathrm{b}}\end{array}$ & $\begin{array}{c}90 \\
(77)^{\mathrm{b}}\end{array}$ & $\begin{array}{c}50 \\
(77) \mathrm{b}\end{array}$ & $p<0,001$ \\
\hline Netinu & $\begin{array}{l}385 \\
(65)\end{array}$ & $\begin{array}{l}118 \\
(66)^{\mathrm{a}}\end{array}$ & $\begin{array}{l}154 \\
(68)^{\mathrm{a}}\end{array}$ & $\begin{array}{l}77 \\
(66)^{\mathrm{a}}\end{array}$ & $\begin{array}{c}33 \\
(51)^{\mathrm{a}}\end{array}$ & $p=0,09$ \\
\hline Bókum & $\begin{array}{l}363 \\
(61)\end{array}$ & $\begin{array}{l}102 \\
(57)^{\mathrm{a}}\end{array}$ & $\begin{array}{l}141 \\
(62)^{\mathrm{a}}\end{array}$ & $\begin{array}{l}78 \\
(67)^{\mathrm{a}}\end{array}$ & $\begin{array}{c}40 \\
(62)^{\mathrm{a}}\end{array}$ & $p=0,41$ \\
\hline Kennaranámi & $\begin{array}{l}326 \\
(55)\end{array}$ & $\begin{array}{c}118 \\
(66)^{\mathrm{a}}\end{array}$ & $\begin{array}{l}136 \\
(60)^{\mathrm{a}}\end{array}$ & $\begin{array}{c}52 \\
(44)^{\mathrm{b}}\end{array}$ & $\begin{array}{c}19 \\
(29) \mathrm{b}\end{array}$ & $p<0,001$ \\
\hline Sérfræðingi/-um & $\begin{array}{l}310 \\
(52)\end{array}$ & $\begin{array}{c}77 \\
(43)^{\mathrm{a}}\end{array}$ & $\begin{array}{l}135 \\
(59)^{\mathrm{b}}\end{array}$ & $\begin{array}{c}66 \\
(56)^{\mathrm{a}, \mathrm{b}}\end{array}$ & $\begin{array}{c}30 \\
(46)^{\mathrm{a}, \mathrm{b}}\end{array}$ & $p=0,006$ \\
\hline Sérkennara/-um & $\begin{array}{l}256 \\
(43)\end{array}$ & $\begin{array}{c}71 \\
(40)^{\mathrm{a}}\end{array}$ & $\begin{array}{c}91 \\
(40)^{\mathrm{a}}\end{array}$ & $\begin{array}{l}63 \\
(54)^{\mathrm{a}}\end{array}$ & $\begin{array}{c}30 \\
(46)^{\mathrm{a}}\end{array}$ & $p=0,06$ \\
\hline $\begin{array}{l}\text { Foreldrum barna } \\
\text { með ADHD }\end{array}$ & $\begin{array}{l}254 \\
(43)\end{array}$ & $\begin{array}{l}76 \\
(43)^{\mathrm{a}}\end{array}$ & $\begin{array}{c}102 \\
(45)^{\mathrm{a}}\end{array}$ & $\begin{array}{c}54 \\
(46)^{\mathrm{a}}\end{array}$ & $\begin{array}{c}22 \\
(34)^{\mathrm{a}}\end{array}$ & $p=0,39$ \\
\hline Sjónvarpi & $\begin{array}{l}244 \\
(41)\end{array}$ & $\begin{array}{c}61 \\
(34)^{\mathrm{a}}\end{array}$ & $\begin{array}{c}100 \\
(44)^{\mathrm{a}}\end{array}$ & $\begin{array}{c}54 \\
(46)^{\mathrm{a}}\end{array}$ & $\begin{array}{c}28 \\
(43)^{\mathrm{a}}\end{array}$ & $p=0,13$ \\
\hline Tímariti/-um & $\begin{array}{l}194 \\
(33)\end{array}$ & $\begin{array}{c}49 \\
(27)^{\mathrm{a}}\end{array}$ & $\begin{array}{c}71 \\
(31)^{\mathrm{a}, \mathrm{b}}\end{array}$ & $\begin{array}{c}50 \\
(43)^{\mathrm{b}}\end{array}$ & $\begin{array}{c}24 \\
(37)^{\mathrm{a}, \mathrm{b}}\end{array}$ & $p=0,04$ \\
\hline $\begin{array}{l}\text { Sem aðstandandi barns/ } \\
\text { fullorðins með ADHD }\end{array}$ & $\begin{array}{l}158 \\
(27)\end{array}$ & $\begin{array}{c}57 \\
(32)^{\mathrm{a}}\end{array}$ & $\begin{array}{c}62 \\
(27)^{\mathrm{a}}\end{array}$ & $\begin{array}{c}27 \\
(23)^{\mathrm{a}}\end{array}$ & $\begin{array}{c}12 \\
(19)^{\mathrm{a}}\end{array}$ & $p=0,14$ \\
\hline Dagblaði/-blöðum & $\begin{array}{l}123 \\
(21)\end{array}$ & $\begin{array}{c}32 \\
(18)^{\mathrm{a}}\end{array}$ & $\begin{array}{l}46 \\
(20)^{\mathrm{a}}\end{array}$ & $\begin{array}{l}30 \\
(26)^{\mathrm{a}}\end{array}$ & $\begin{array}{c}14 \\
(22)^{\mathrm{a}}\end{array}$ & $p=0,45$ \\
\hline $\begin{array}{l}\text { Ég hef sjálf/-ur verið } \\
\text { greind/-ur með ADHD. }\end{array}$ & $\begin{array}{l}36 \\
(6)\end{array}$ & $\begin{array}{c}20 \\
(11)^{\mathrm{a}}\end{array}$ & $\begin{array}{c}9 \\
(4)^{b}\end{array}$ & $\begin{array}{c}5 \\
(4)^{\mathrm{a}, \mathrm{b}}\end{array}$ & $\begin{array}{c}1 \\
(2)^{\mathrm{a}, \mathrm{b}}\end{array}$ & $p=0,004$ \\
\hline
\end{tabular}

Ath. Hólf i sömu rö̀ sem marktakur munur var á við leiðréttan eftirásamanburð með z-prófi $(\mathbf{p}<0,05)$ eru merkt með mismunandi bókstöfum (p.e. „a“ eða „b“) i brjóstletri (e. superscript) en hólf i sömu röð par sem munur var ekki marktakur eru merkt með sama bókstafl-stöfum.

\section{Aðferðir og áherslur í stuðningi við nemendur með ADHD}

Á Mynd 1 má sjá hvaða aðferðum pátttakendur sögðust helst beita til að styðja nemendur með ADHD. Algengast var að pátttakendur segðust skipta námsefni barns með ADHD niður í smærri einingar (79\%). Minna en helmingur (44\%) pátttakenda sagðist styrkja einbeitingu/námsástundun nemenda með kerfisbundnum hætti og um 7\% sögðust nota aðrar (ótilgreindar) aðferðir. Ekki mældist marktækur munur milli hópa eftir starfsaldri á heildarfjölda stuðningsaðferða byggðum á klínískum leiðbeiningum sem pátttakendur sögðust nýta í kennslu $F(3,582)=2,15, p=0,093$. Einu marktæku tengslin milli starfsaldurs pátttakenda og stuðningsaðferða mældust fyrir aðferðina að veita stutt hlé milli tímabila par sem kröfur eru gerðar um einbeitingu $X^{2}(3, N=589) 9,33, p=0,025$, par sem marktækt lægra hlutfall pátttakenda með lengsta starfsaldurinn merkti við pá aðferð en pátttakendur með styttri starfsaldur. Hins vegar mældist marktækur munur milli hópa eftir skólastigi á 
heildarfjölda stuðningsaðferða sem pátttakendur sögðust nýta $F(2,575)=3,73, p=0,025$, par sem eftirásamanburður sýndi að kennarar á yngsta stigi merktu við marktækt fleiri aðferðir að meðaltali $(4,6)$ en kennarar á unglingastigi $(4,1) p=0,020$.

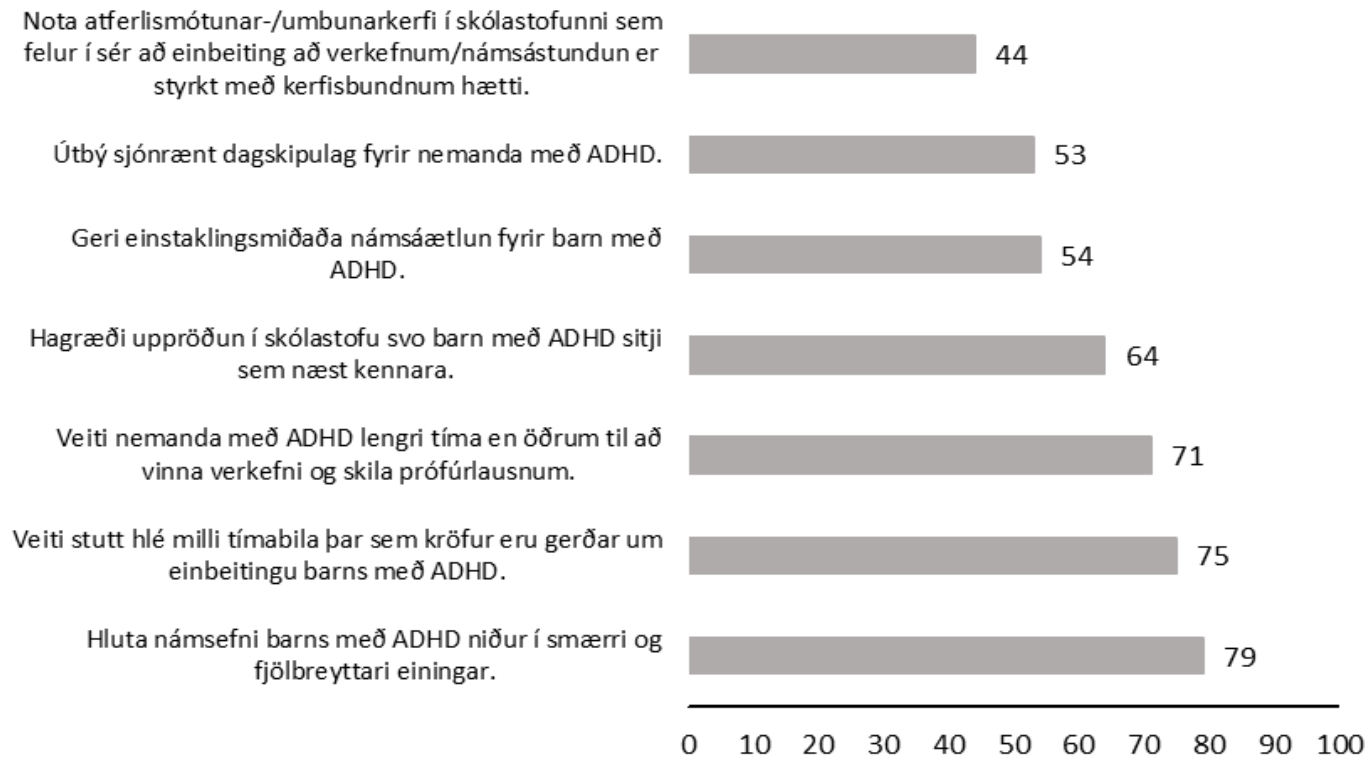

Útbý sjónrænt dagskipulag fyrir nemanda með ADHD.

Geri einstaklingsmiðaða námsáætlun fyrir barn með ADHD.

53

54

Hagræði uppröđun í skólastofu svo barn með ADHD sitji sem næst kennara.

64

Veiti nemanda með ADHD lengri tíma en öðrum til að̉ vinna verkefni og skila prófúrlausnum.

Veiti stutt hlé milli tímabila par sem kröfur eru gerðar um einbeitingu barns með ADHD.

Hluta námsefni barns með ADHD niður í smærri og fjölbreyttari einingar.

Mynd 1. Hlutfall pátttakenda (í\%) sem merktu við hverja stuðningsaðferð.

Jafnframt mældust marktæk tengsl milli skólastigs pátttakenda og mismunandi stuðningsaðferða (sjá nánar í Töflu 2). Hærra hlutfall pátttakenda sem kenndu á mið- og unglingastigi (75-79\%) sagðist veita nemendum lengri tíma en pátttakendur við kennslu á yngsta stigi (60\%). Hærra hlutfall pátttakenda á unglingastigi (62\%) sagðist gera einstaklingsmiðaða námsáætlun samanborið við pátttakendur á yngsta stigi (47\%). Á hinn bóginn voru fleiri pátttakendur sem kenndu á yngsta stigi (71\%) en á unglingastigi (57\%) sem sögðust hagræða uppröðun í skólastofu og sömuleiðis var hlutfall pátttakenda á yngsta stigi kennslu sem merkti við kerfisbundna styrkingu námsástundunar hærra (59\%) en meðal pátttakenda á mið- (42\%) og unglingastigi (31\%). Marktækt hærra hlutfall pátttakenda á yngsta stigi (67\%) merkti við notkun sjónræns dagskipulags en á efri stigum og jafnframt var marktækt hærra hlutfall pátttakenda á miðstigi (55\%) sem merkti við pann möguleika en á unglingastigi (38\%). 
Tafla 2. Samanburður á fjölda/hlutfalli pátttakenda sem merktu við mismunandi aðferðir við kennslu nemenda með ADHD eftir skólastigi.

\begin{tabular}{|c|c|c|c|c|c|}
\hline \multirow[b]{3}{*}{$\begin{array}{l}\text { Hluta námsefni barns með } \\
\text { ADHD niður í smærri og fjöl- } \\
\text { breyttari einingar. }\end{array}$} & \multicolumn{5}{|c|}{ Hópar pátttakenda eftir skólastigi } \\
\hline & $\begin{array}{l}\text { Heild } \\
n(\%)\end{array}$ & $\begin{array}{l}\text { Yngsta stig } \\
n(\%)\end{array}$ & $\begin{array}{l}\text { Miðstig } \\
n(\%)\end{array}$ & $\begin{array}{c}\text { Unglingastig } \\
n(\%)\end{array}$ & $\begin{array}{l}\text { Niðurstöður } \\
\text { kí-kvaðrat- } \\
\text { prófs á tengsl- } \\
\text { um milli } \\
\text { breyta }\end{array}$ \\
\hline & $\begin{array}{l}457 \\
(79)\end{array}$ & $\begin{array}{c}162 \\
(82)^{\mathrm{a}}\end{array}$ & $\begin{array}{c}151 \\
(79)^{\mathrm{a}}\end{array}$ & $\begin{array}{c}144 \\
(76)^{\mathrm{a}}\end{array}$ & $p=0,297$ \\
\hline $\begin{array}{l}\text { Veiti stutt hlé milli tímabila par } \\
\text { sem kröfur eru gerðar um ein- } \\
\text { beitingu barns með ADHD. }\end{array}$ & $\begin{array}{l}435 \\
(75)\end{array}$ & $\begin{array}{l}155 \\
(79)^{\mathrm{a}}\end{array}$ & $\begin{array}{l}145 \\
(76)^{\mathrm{a}}\end{array}$ & $\begin{array}{l}135 \\
(71)^{\mathrm{a}}\end{array}$ & $p=0,214$ \\
\hline $\begin{array}{l}\text { Veiti nemanda með ADHD } \\
\text { lengri tíma en öðrum til að vinna } \\
\text { verkefni og skila prófúrlausnum. }\end{array}$ & $\begin{array}{l}411 \\
(71)\end{array}$ & $\begin{array}{c}118 \\
(60)^{\mathrm{a}}\end{array}$ & $\begin{array}{c}143 \\
(75)^{\mathrm{b}}\end{array}$ & $\begin{array}{c}150 \\
(79)^{\mathrm{b}}\end{array}$ & $p<0,001$ \\
\hline $\begin{array}{l}\text { Hagræði uppröðun í skólastofu } \\
\text { svo barn með ADHD sitji sem } \\
\text { næst kennara. }\end{array}$ & $\begin{array}{l}369 \\
(64)\end{array}$ & $\begin{array}{l}140 \\
(71)^{\mathrm{a}}\end{array}$ & $\begin{array}{c}121 \\
(63)^{\mathrm{a}, \mathrm{b}}\end{array}$ & $\begin{array}{c}109 \\
(57)^{\mathrm{b}}\end{array}$ & $p=0,014$ \\
\hline $\begin{array}{l}\text { Geri einstaklingsmiðaða námsá- } \\
\text { ætlun fyrir barn með ADHD. }\end{array}$ & $\begin{array}{l}312 \\
(54)\end{array}$ & $\begin{array}{c}92 \\
(47)^{\mathrm{a}}\end{array}$ & $\begin{array}{c}102 \\
(53)^{\mathrm{a}, \mathrm{b}}\end{array}$ & $\begin{array}{l}118 \\
(62)^{b}\end{array}$ & $p=0,010$ \\
\hline $\begin{array}{l}\text { Útbý sjónrænt dagskipulag fyrir } \\
\text { nemanda með ADHD. }\end{array}$ & $\begin{array}{l}308 \\
(53)\end{array}$ & $\begin{array}{l}131 \\
(67)^{\mathrm{a}}\end{array}$ & $\begin{array}{c}104 \\
(55)^{\mathrm{b}}\end{array}$ & $\begin{array}{c}73 \\
(38)^{\mathrm{c}}\end{array}$ & $p<0,001$ \\
\hline $\begin{array}{l}\text { Nota atferlismótunar-/umbunar- } \\
\text { kerfi í skólastofunni sem felur í } \\
\text { sér að einbeiting að verkefnum/ } \\
\text { námsástundun er styrkt með } \\
\text { kerfisbundnum hætti. }\end{array}$ & $\begin{array}{l}256 \\
(44)\end{array}$ & $\begin{array}{l}117 \\
(59)^{\mathrm{a}}\end{array}$ & $\begin{array}{c}80 \\
(42)^{\mathrm{b}}\end{array}$ & $\begin{array}{c}59 \\
(31)^{\mathrm{b}}\end{array}$ & $p<0,001$ \\
\hline
\end{tabular}

Ath. Hólf i sömu röð sem marktakur munur var á við leiðréttan eftirásamanburð með z-prófi $(p<$ 0,05) eru merkt með mismunandi bókstöfum (p.e. „a“, „b“ " eða „c“) i brjóstletri (e. superscript) en hólf i sömu röð par sem munur var ekki marktakur eru merkt með sama bókstafl-stöfum.

Algengasta aðferðin við að mæla breytingar á hegðun nemanda með ADHD í skólastofu var að fylgjast með nemandanum (87\%), par á eftir að tala við samstarfsfólk um hegðun nemandans (74\%), og rúmur helmingur (54\%) pátttakenda sagðist meta hegðun byggt á eigin reynslu (sjá Mynd 2). Aðeins um fjórðungur pátttakenda sagðist skrá tíðni æskilegrar/óæskilegrar hegðunar og rétt rúm $5 \%$ sögðust taka tímann. Prátt fyrir að dreifigreining leiddi í ljós marktækan mun milli starfsaldurshópa á heildarfjölda mæliaðferða við mat á árangri af stuðningi $F(3,585)=2,81, p=0,039$ voru afköst eftirásamanburðar með Bonferroni-leiðréttingu ekki nægjanleg til pess greina hvar sá munur lægi. Niðurstöður kí-kvaðratprófs bentu til pess að marktæk tengsl væru milli starfsaldurshóps og pess hvort pátttakendur segðust mæla breytingar á hegðun nemenda með ADHD byggt á reynslu, $X^{2}(3, N=589) 17,36, p=0,001$, par sem lægra hlutfall pátttakenda með lægsta starfsaldurinn valdi pann möguleika en pátttakendur með lengri starfsaldur. Ekki komu fram marktæk tengsl milli starfsaldurs og annarra mæliaðferða. Hvorki kom fram marktækur munur milli skólastigshópa á heildarfjölda mæliaðferða við mat á árangri né marktæk tengsl milli skólastigshópa og mismunandi mæliaðferða. 


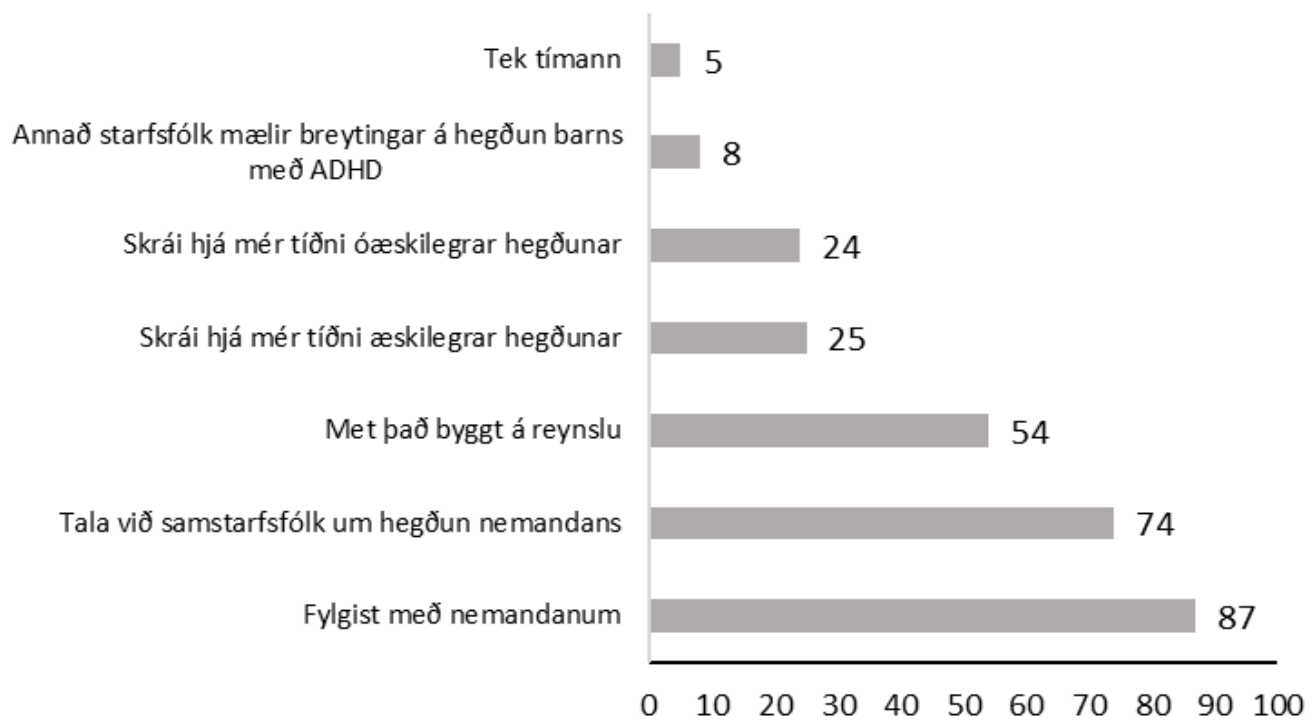

Mynd 2. Hlutföll pátttakenda (í \%) sem merktu við hverja aðferð við að mæla breytingar í hegðun barns með ADHD.

Pær aðferðir sem pátttakendur sögðust helst mæla með við aðra vegna ADHD (sjá Mynd 3) voru hreyfing (69\%), að leita til sérfræðilæknis vegna lyfjameðferðar (67\%) og að leita sálfræðipjónustu (54\%). Hvorki mældist marktækur munur milli hópa eftir starfsaldri á heildarfjölda aðferða sem pátttakendur sögðust mæla með við aðra vegna $\mathrm{ADHD}, F(3,585)=2,57, p=0,053$, né eftir skólastigi $F(2,575)=0,93, p=$ 0,397. Niðurstöður kí-kvaðratprófs sýndu að marktæk tengsl voru milli starfsaldurshóps og pess hvort pátttakendur segðust mæla með höfuðbeina- og spjaldhryggjarmeðferð við aðra vegna $\mathrm{ADHD} X^{2}(3, N=$ 589) $13,89, p=0,003$ en pátttakendur með styttri starfsaldur merktu síður við pann möguleika en pátttakendur með lengri starfsaldur og pess hvort mælt væri með hómópatíu $X^{2},(3, N=589) 8,84, p=0,03$ og breyttu mataræði, $X^{2}(3, N=589) 8,51, p=0,04$ en afköst eftiráprófa voru ekki nægjanleg til að meta hvar sá munur lá. Einnig komu fram marktæk tengsl milli skólastigs og aðferða sem pátttakendur mæltu með, pað er hómópatíu, $X^{2}(2, N=578) 13,06, p=0,001$ sem pátttakendur á miðstigi merktu frekar við en hinir hóparnir, vítamína/bætiefna, $X^{2}(2, N=578) 9,74, p=0,008$ sem pátttakendur á mið- og unglingastigi merktu frekar við en pátttakendur á yngsta stigi og námskeiða, $X^{2}(2, N=578) 9,65, p=0,008$ sem pátttakendur á yngsta og unglingastigi merktu frekar við en pátttakendur á miðstigi.

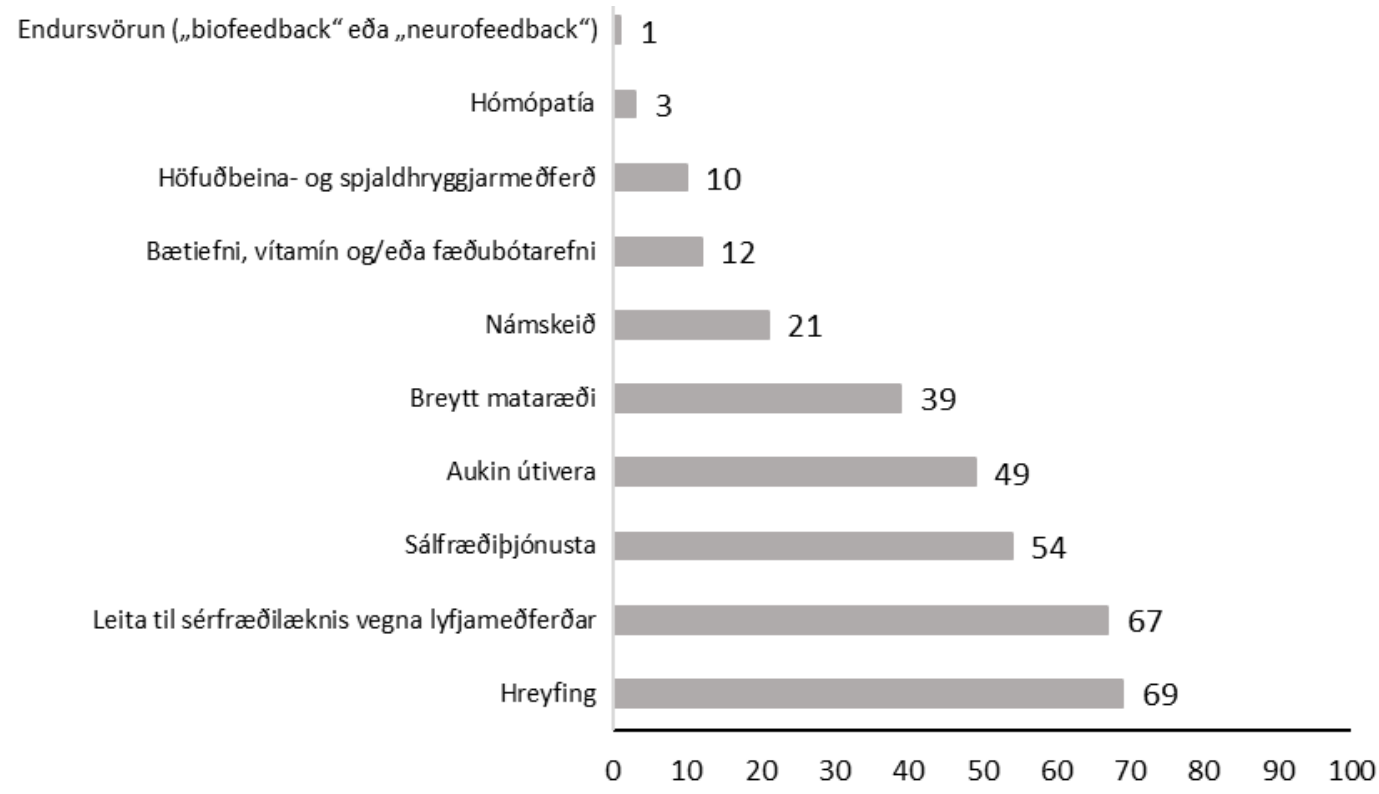

Mynd 3. Hlutföll pátttakenda (í \%) sem merktu við hverja aðferð sem peir myndu mæla með vegna barns með ADHD. 


\section{Hindranir og stuðningur við kennslu nemenda með ADHD}

Helstu hindranir árangursríkrar kennslu nemenda með ADHD, að mati pátttakenda, voru fjöldi barna í bekknum með sérparfir (69\%), stærð bekkjar (61\%) og kröfur um að sinna verkefnum öðrum en kennslu (52\%) en niðurstöður hópsins í heild má sjá á Mynd 4. Tæpur fimmtungur (18\%) pátttakenda sagði að ráðlagðar kennsluaðferðir sérfræðinga virkuðu ekki nógu vel og rúmur fjórðungur (27\%) taldi skort á pjálfun eina af hindrunum í starfi. Hvorki reyndist marktækur munur á fjölda tilgreindra hindrana eftir starfsaldurshópi $\mathrm{F}(3,585)=1,95, \mathrm{p}=0,121$ né eftir skólastigi $\mathrm{F}(2,575)=1,01, \mathrm{p}=0,366$. Kí-kvaðratpróf leiddu hins vegar í ljós marktæk tengsl milli starfsaldurshóps og ýmissa hindrana í starfi, pað er skortur á viðeigandi kennsluefni $\mathrm{X}^{2}(3, \mathrm{~N}=589)$ 14,01, $\mathrm{p}=0,003$ sem hópurinn með lengsta starfsaldurinn merkti frekar við en hinir hóparnir, skortur á pjálfun í að kenna börnum með $\operatorname{ADHD~X}^{2}(3, \mathrm{~N}=589)$ 13,96, p = 0,003 sem pátttakendur með 1-20 ára starfsaldur merktu frekar við en hópar með lengri starfsreynslu, hversu alvarleg einkenni barnsins eru, $\mathrm{X}^{2}(3, \mathrm{~N}=589) 8,58, \mathrm{p}=0,04$ og venjulegar kennsluaðferðir nýtast ekki nógu vel, $\mathrm{X}^{2}(3, \mathrm{~N}=589) 8,49, \mathrm{p}=0,04$ en í síðustu tveimur tilvikunum voru afköst eftiráprófa ekki næg til að greina hvar sá munur lá. Hvað tengsl milli skólastigs og hindrana í starfi varðar mældust pau aðeins marktæk í tilfelli skorts á samvinnu við lækna varðandi parfir barnsins: $\mathrm{X}^{2}(2, \mathrm{~N}=578) 7,93, \mathrm{p}=$ 0,019 par sem pátttakendur á miðstigi merktu frekar við pann svarmöguleika en pátttakendur á yngsta eða unglingastigi.

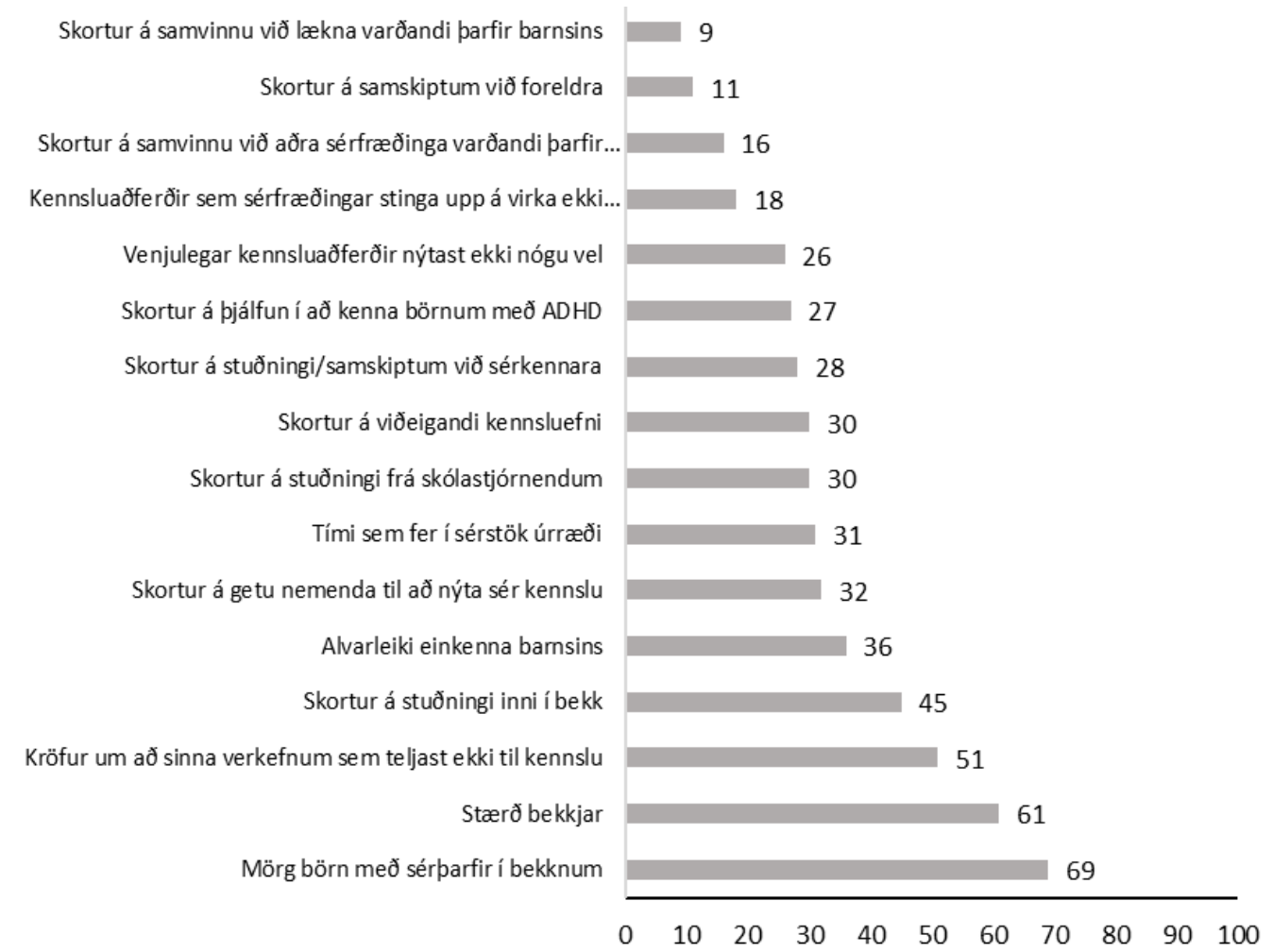

Mynd 4. Hlutföll pátttakenda (í) sem merktu við hverja hindrun í starfi við kennslu barns með ADHD.

Tæp 28\% pátttakenda sögðust pekkja aðferðir byggðar á atferlismótun (s.s. markvissa hvatningu) „frekar illa“ eða „mjög illa“ en um 32\% sögðust pekkja pær „frekar eða mjög vel“. Um 32\% pátttakenda sögðust pekkja klínískar leiðbeiningar Embættis landlæknis um vinnulag við greiningu og meðferð ADHD „frekar illa“ eða „mjög illa“ og um 25\% sögðust pekkja pær „frekar vel“ eða „mjög vel“.

Um 46\% pátttakenda töldu sig ná að sinna nemendum með ADHD „frekar vel“ eða „mjög vel“ í starfi sínu en um $21 \%$ töldu sig sinna peim „frekar illa“ eða „mjög illa“. Pátttakendur sem sögðust „frekar ánægð/-ur" eða „mjög ánægð/-ur" með aðstoð við kennslu nemenda með ADHD voru um 26\% en pátttakendur sem merktu við „frekar óánægð/-ur“ eða „mjög óánægð/-ur" voru um 36\%. 
Samtals $n=286$ (48\%) pátttakendur sögðu að annað fagfólk hefði veitt sér stuðning við kennslu nemenda með ADHD. Pátttakendur tilgreindu oftast að sérkennari veitti pann stuðning (31,3\%), par á eftir skólasálfræðingur (18,4\%) og proskabjálfi (18,2\%), sérfræðingur skólaskrifstofu (17,4\%) og svo námsráðgjafi (15,5\%), iðjupjálfi (6,3\%) og skólahjúkrunarfræðingur (4,2\%). Tæp 48\% pátttakenda sögðu flæði upplýsinga milli starfsfólks skólans um nemendur með ADHD „frekar gott“ eða „mjög gott“ en um 24\% pátttakenda sögðu flæði upplýsinga „frekar slæmt“ eða „mjög slæmt“.

\section{Umræða}

Börn og ungmenni með ADHD eru líklegri til að standa höllum fæti á ýmsum sviðum daglegs lífs samanborið við jafnaldra sem eru ekki með röskunina, allt fram á fullorðinsár (Uchida o.fl., 2018). Starfsfólk skóla, einkum kennarar, gegnir mikilvægu hlutverki við að stuðla að farsælum proska pessara nemenda. Markmið höfunda var að kanna mat starfandi grunnskólakennara á Íslandi á hvert peir sæktu pekkingu sína, hversu vel peir teldu námið hafa búið sig undir kennslu pessara nemenda og hverjar helstu aðferðir og áherslur peirra væru í stuðningi við pennan hóp. Byggt var á sambærilegri rannsókn Jónínu Sæmundsdóttur (2009) með viðbótum. Helstu niðurstöður bentu til pess að kennaranám gæti hafa breyst pannig að pað búi verðandi kennara betur en áður undir starf með nemendum með ADHD og að starfandi kennarar noti langflestir einhverjar gagnreyndar aðferðir til pess að styðja við nemendur með röskunina, en að jafnframt sé pörf fyrir aukinn faglegan stuðning við stéttina. Hér í umræðukafla verður vikið að pví hversu vel pær aðferðir sem pátttakendur sögðust beita í kennslu eru studdar rannsóknum og hvaða pýðingu niðurstöðurnar hafa fyrir grunnskólakennara á Íslandi og starfspróun peirra.

\section{Pekking kennara á ADHD og undirbúningur að námi loknu}

Helsta uppspretta pekkingar á ADHD meðal pátttakenda í pessari rannsókn var kennsla nemenda með röskunina en rúmlega 9 af hverjum 10 pátttakendum merkti við pann möguleika. Í öðru sæti voru fyrirlestrar og í kjölfarið komu námskeið, netið og bækur. Í samanburði við niðurstöður Jónínu Sæmundsdóttur (2009) voru hins vegar bækur næstalgengasta uppspretta pekkingar og fyrirlestrar sú priðja algengasta. Pví virðist sem einhverjar breytingar hafi orðið á hvert starfandi kennarar sækja pekkingu sína um ADHD. Næstum fimmtungur pátttakenda í pessari rannsókn sagði nám sitt hafa búið sig frekar vel eða mjög vel undir kennslu pessa nemendahóps, sem er töluvert hærra hlutfall en áður, eða aðeins 6\% (Jónína Sæmundsdóttir, 2009). Sérstaklega áhugavert var að marktæk tengsl mældust milli starfsaldurs og mats á undirbúningi í námi, par sem marktækt fleiri kennarar með stysta starfsaldurinn en kennarar með hærri starfsaldur sögðust sækja pekkingu sína um ADHD til kennaranáms. Hins vegar var hópur kennara með stysta starfsaldurinn ólíklegri til að afla sér pekkingar um ADHD á námskeiðum, fyrirlestrum og hjá sérfræðingum en reynslumeiri kennarar. Pátttakendur með meiri starfsreynslu mátu sig verr búna undir kennslu barna með ADHD að námi loknu en hópur pátttakenda með stystu starfsreynsluna. Væntanlega er almennt styttra síðan hópurinn með minnstu starfsreynsluna útskrifaðist úr háskólanámi en hópur kennara með meiri starfsreynslu. Pessar niðurstöður gætu pví verið vísbending um að innihald og efnistök kennaranáms hafi tekið einhverjum breytingum í pá átt að kennarar telji sig betur búna undir starf með nemendum með ADHD, pótt pær gefi ekki tilefni til endanlegra fullyrðinga um pað. Eins getur verið að reyndari kennarar sæki sér endurmenntun til að „bæta upp“ fyrir pað sem peir telja að nám peirra hafi skort, til dæmis með pví að sækja fyrirlestra, námskeið og/eða leita til sérfræðinga. Petta eru pó aðeins getgátur sem kanna pyrfti nánar.

\section{Aðferðir og áherslur kennara í stuðningi við nemendur með ADHD}

Undirstaða árangursríks stuðnings við nemendur með ADHD er að kennarar og annað starfsfólk skóla búi yfir pekkingu og færni í gagnreyndum aðferðum. Miðað við niðurstöður pessarar rannsóknar virðist meirihluti starfandi grunnskólakennara á Íslandi beita að minnsta kosti einhverjum 
peirra aðferða sem taldar eru upp í klínískum leiðbeiningum Embættis landlæknis vegna greiningar og meðferðar ADHD og í samræmi við helstu rannsóknir á sviðinu (Evans o.fl., 2014). Flestir pátttakendur sögðust skipta námsefni nemenda með ADHD niður í smærri einingar, veita peim hlé milli vinnulota og lengri tíma til að ljúka verkefnum og/eða prófum en aðeins $2 \%$ sögðust ekki nota neinar sérstakar aðferðir í pessu samhengi. Hins vegar er athyglisvert að minna en helmingur pátttakendahópsins í heild sagðist styrkja viðeigandi hegðun nemenda með ADHD (til dæmis einbeitingu og námsástundun) með kerfisbundnum hætti. Rannsóknir hafa ítrekað sýnt að samhliða fyrirbyggjandi aðferðum (t.d. aðlöguðu námsumhverfi, skýrum fyrirmælum o.fl.) er markviss hvatning (s.s. lýsandi hrós, jákvæð athygli, umbunar- og táknkerfi) til að kenna nýja hegðun og viðhalda henni til lengri tíma, eitt af grundvallaratriðum árangursríks stuðnings við pennan nemendahóp (DuPaul o.fl., 2012; Pfiffner og DuPaul, 2014). Í samantekt Evans og félaga (2014) á gagnreyndum úrræðum vegna $\mathrm{ADHD}$ var bekkjarstjórnun sem byggist á pessum sömu aðferðum, pað er fyrirbyggjandi aðgerðum samhliða markvissri hvatningu, einnig skilgreind sem rótgróið (e. well-established) úrræði. Niðurstöður íslenskra rannsókna benda til pess að einmitt pessar aðferðir styðji við framfarir í hegðun og námsástundun nemenda (Guðrún Björg Ragnarsdóttir og Anna-Lind Pétursdóttir, 2013) og að peim líki pær vel (Sesselja Árnadóttir og Anna-Lind Pétursdóttir, 2013). Svipað og hjá Hart og félögum (2017) kom í ljós í pessari rannsókn að kennarar nemenda á yngsta stigi nýttu að meðaltali marktækt fleiri stuðningsaðferðir við kennslu barna með ADHD en kennarar barna á miðog unglingastigi. Við nánari athugun sást að meira en helmingur kennara nemenda á yngsta stigi beitti markvissri styrkingu hegðunar. Pessi hópur sagðist einnig frekar hagræða uppröðun í skólastofu og nýta sjónrænt dagskipulag en hópur kennara eldri nemenda. Hins vegar sögðust kennarar á efri stigum frekar nýta einstaklingsmiðaða námsáxtlun og veita nemendum lengri tíma í verkefnum og á prófum en kennarar yngri nemenda.

Á heildina litið er sennilegt að starfandi kennarar og annað starfsfólk grunnskóla á Íslandi hefði gagn af að læra um og fá handleiðslu við að nýta pessar aðferðir, sem væri nemendum einnig til hagsbóta. Petta samræmist niðurstöðum erlendra rannsókna sem benda til pess að verðandi og starfandi kennara skorti pekkingu á ADHD (Anderson o.fl., 2012; Bekle, 2004; Jerome o.fl., 1994; Kos o.fl., 2004; Mulholland o.fl., 2015; Poznanski o.fl., 2018) og árangursríkum úrræðum fyrir pennan nemendahóp (Anderson o.fl., 2012). Miðað við pessar niðurstöður er mögulegt að sníða pyrfti pessa pjálfun að pörfum kennara eftir skólastigi; til dæmis mætti leggja aukna áherslu á einstaklingsmiðaða námsáætlun meðal kennara yngri barna og benda kennurum á efri stigum á hagnýtt gildi sjónræns dagskipulags fyrir nemendur með ADHD. Prátt fyrir að hærra hlutfall kennara yngri en eldri barna hafi greint frá notkun markvissrar styrkingar hegðunar voru engu að síður um $40 \%$ pátttakenda í peim hópi sem gerðu pað ekki. Par af leiðandi væri skynsamlegt að efla færni allra kennara í peirri aðferð, óháð skólastigi.

Mat á árangri stuðnings og framförum nemenda með ADHD er ein af forsendum pess að stuðningur innan skóla hafi tilætluð áhrif (sjá t.d. Haraway, 2012) og mælingar á árangri (e. progress monitoring) purfa að vera áreiðanlegar og réttmætar til pess að nýtast sem best (Deno, 2005). Í pessari rannsókn sagðist meirihluti pátttakenda meta breytingar á hegðun nemanda með ADHD með pví að fylgjast með nemandanum, sem ætla má að feli í sér einhvers konar „klínískt“ mat á stöðu nemandans. Par á eftir sagðist meirihluti pátttakenda ræða hegðun nemandans við samstarfsfólk og rétt rúmur helmingur sagðist meta pað byggt á eigin reynslu. Hvað megindlegt árangursmat varðar greindi aðeins fjórðungur pátttakenda frá pví að skrá tíðni tiltekinnar hegðunar. Pótt klínískt mat fagfólks sé gjarnan hluti af heildstæðu mati á stöðu og framförum nemenda með ADHD benda rannsóknir til pess að gagnreyndar matsaðferðir, sérstaklega pær sem byggjast á megind- eða tölfræðilegum (e. actuarial) gögnum, séu ekki síður mikilvægar við mat á árangri stuðnings (Canivez, 2019). Miðað við pessar niðurstöður er pví sennilegt að starfandi grunnskólakennarar á Íslandi fái ekki eins skýra mynd af árangri stuðnings, eða skorti á honum, og æskilegt væri. Pað er óheppilegt, par sem pað dregur væntanlega úr líkum á að árangursríkum stuðningi við nemendur með ADHD sé viðhaldið og/eða að aðferðum sem bera takmarkaðan eða jafnvel engan árangur sé breytt.

Áðurnefndar niðurstöður um mat á árangri meðal nemenda með ADHD má einnig tengja við pær aðferðir sem pátttakendur sögðust helst mæla með við aðra vegna ADHD, en gera má ráð fyrir 
að peir mæli aðeins með pví sem peir telja að beri árangur. Pátttakendur í pessari rannsókn sögðust flestir mæla með hreyfingu, pjónustu sérfræðilækna vegna lyfjameðferðar og sálfræðibjónustu en niðurstöður rannsókna styðja almennt jákvæð áhrif allra pessara aðferða (sjá nánar um áhrif hreyfingar: Vysniauske o.fl., 2020), pótt aðeins lyfjameðferð (Catalá-López o.fl., 2017; Connor, 2014; Cortese o.fl., 2018) og ákveðnar tegundir sálfræðimeðferðar (Evans o.fl., 2014; Evans o.fl., 2018) teljist formlega gagnreynd meðferðarúrræði. Einnig voru aukin útivera og breytt mataræði ofarlega á pessum lista en hvorugt pessara úrræða við ADHD telst gagnreynt (sjá nánar um tengsl mataræðis og ADHD-einkenna: Uldall Torp og Thomsen, 2020) pótt verið geti að rannsóknir eigi eftir að leiða betur í ljós mögulegan ávinning peirra. Til dæmis benda einhverjar rannsóknir til pess að svokölluð endursvörun (e. biofeedback; neurofeedback) geti hugsanlega dregið úr ADHD-einkennum, pótt sú aðferð teljist ekki gagnreynd (Evans o.fl., 2018). Höfundar telja pað umhugsunarefni að pónokkur hópur pátttakenda í pessari rannsókn sagðist mæla með aðferðum sem almennt eru ekki studdar rannsóknum í meðferð við ADHD, til dæmis bætiefnum, vítamínum og/eða fæðubótarefnum, höfuðbeina- og spjaldhryggjarmeðferð og hómópatíu (sjá t.d. Coulter og Dean, 2007; Jäkel og von Hauenschild, 2012; Lange o.fl., 2017). Á heildina litið benda pessar niðurstöður til pess að gagnlegt væri fyrir kennara að fá aukna fræðslu og pjálfun í mati á árangri stuðnings við nemendur með ADHD, samhliða fræðslu og pjálfun annars vegar um pær aðferðir sem rannsóknir hafa sýnt að beri árangur og hins vegar um ýmis úrræði sem ekki teljast árangursrík í meðferð við ADHD. Brýnt er að fagfólk verji kröftum sínum og tíma aðeins í pær aðferðir sem líklegastar eru til að auka lífsgæði nemenda með ADHD, frekar en pað sem fá eða jafnvel engin gögn benda til að nýtist kennurum eða nemendum.

\section{Hindranir og stuðningur í starfi við kennslu nemenda með ADHD}

Skortur á pjálfun virðist pó ekki vera algengasta hindrunin við kennslu pessa nemendahóps en aðeins rúmur fjórðungur pátttakenda merkti við pann svarmöguleika. Algengast var að pátttakendur segðu að fjöldi nemenda með sérparfir í bekknum væri peim hindrun í starfi, næstalgengust var stærð bekkjar og par á eftir verkefni önnur en kennsla, skortur á stuðningi inni í bekk og alvarleiki ADHD-einkenna nemenda. Pessar niðurstöður eru mjög svipaðar niðurstöðum Jónínu Sæmundsdóttur (2009) og virðist pví fátt hafa breyst meðal starfandi kennara hvað hindranir í starfi snertir. Athygli vekur að tæpur fimmtungur pátttakenda sagði ráðleggingar sérfræðinga ekki virka nógu vel.

Aðspurðir um stuðning í starfi var algengast að pátttakendur segðust leita til sérkennara, par á eftir til skólasálfræðings og proskapjálfa. Rétt tæpur helmingur pátttakenda sagði flæði upplýsinga milli starfsfólks skólans um nemendur með ADHD frekar eða mjög gott en aðeins um fjórðungur að pað væri frekar eða mjög slæmt. Petta er frábrugðið fyrri niðurstöðum Jónínu Sæmundsdóttur (2009) par sem meira en helmingur pátttakenda taldi upplýsingagjöf milli starfsfólks skóla ófullnægjandi og gæti bent til pess að starfsfólk skóla miðli upplýsingum um nemendur með ADHD sín á milli í meira mæli en áður.

Ljóst er að eftir pví sem nemendum með sérparfir fjölgar í hverjum bekk aukast kröfur og álag í starfi meðal kennara, ekki síst ef pá skortir faglegan stuðning. Mikilvægt er að bregðast við pessu, til pess að styðja við bæði kennara og nemendur, en niðurstöður pessarar rannsóknar sýndu jafnframt að rúmur fimmtungur pátttakenda teldi sig sinna nemendum með ADHD frekar eða mjög illa. Rúmur priðjungur var auk pess frekar eða mjög óánægður með aðstoð við kennslu pessara nemenda. Раð að ráðleggingar sérfræðinga og/ eða annar stuðningur við kennslu nemenda með ADHD nýtist starfandi grunnskólakennurum ekki nógu vel er áhyggjuefni. Nauðsynlegt er að ráðgjöf til kennara um nemendur sem purfa á sérstökum stuðningi að halda sé hagnýt og valdeflandi fyrir kennara, pað er að hún auki trú peirra á eigin getu. Rannsaka parf betur hvað felst í góðri ráðgjöf og stuðningi að mati grunnskólakennara og sömuleiðis hvort nám, starfspróun og starfsumhverfi kennara gerir peim kleift að nýta sér ráðgjöf og stuðning annarra eins vel og æskilegt væri. Sennilega eru tækifæri til umbóta bæði í námi, starfspróun og vinnuumhverfi kennara og peirri ráogjöf sem peim er veitt á vettvangi.

Miðað við niðurstöður virtist aðeins minnihluti kennara nýta ákveðnar áhrifaríkar, gagnreyndar aðferðir, svo sem hvatningarkerfi, eða pekkja vel til klínískra leiðbeininga Embættis landlæknis um ADHD. Í 
samhengi við áðurnefndar niðurstöður bendir petta til pess að markviss pjálfun í gagnreyndum aðferðum gæti nýst kennurum og nemendum peirra með ADHD. Mikilvægt er að hafa í huga að pótt fræðsla til kennara um röskunina geti mögulega aukið pekkingu peirra virðist fræðsla ein og sér ekki hafa áhrif á hegðun nemenda peirra, miðað við niðurstöður nýlegrar samantektar fjölda rannsókna á áhrifum ADHD-fræðslu í kennaranámi (Ward o.fl., 2020). Á hinn bóginn teljast markviss ráđgjöf, stuðningur og/ eða handleiðsla sérfræðinga til kennara um hegðun (e. behavioral consultation) viðurkennt verklag (e. best practice) í forvörnum og stuðningi innan skóla (Kratochwill o.fl., 2014). Ráðgjöf/handleiðsla af pessu tagi virðist enda árangursrík við að efla gagnreynd vinnubrögð kennara, auka jákvæð samskipti kennara og nemenda og bæta hegðun nemenda (Conroy o.fl., 2014). Jákvæð áhrif ráðgjafar/handleiðslu virðast koma skjótt fram ef marka má bandaríska frumrannsókn par sem sameiginleg handleiðsla og ráogjöf til kennara og foreldra barna með ADHD um stuðningsaðferðir af pessu tagi (e. conjoint behavioral consultation) í aðeins prjú til fjögur skipti dró úr ADHD-einkennum barnanna, allavega til skemmri tíma, en að meiri stuðnings gæti verið pörf til pess að halda árangri við til lengri tíma (Gormley o.fl., 2020).

Nemendur með ADHD eru jafn fjölbreyttir og peir eru margir, rétt eins og jafnaldrar peirra sem ekki greinast með röskunina, og pví er nauðsynlegt að skólar fylgi heildstæðu verklagi í allri kennslu og stuðningi við nemendur. Dæmi um pað er svokallaður prepa- eða stigskiptur stuðningur við nemendur (e. multi-tiered systems of support; MTSS), sem gerir ráð fyrir mismikilli stuðningspörf nemenda, óháð formlegri greiningu á $\mathrm{ADHD}$ og/eða öðrum röskunum, og veitir viðeigandi stuðning í samræmi við pá pörf, en petta er viðurkennt verklag í forvörnum og snemmtækri íhlutun innan skóla (Stoiber, 2014). Innan pess verklags rúmast sannarlega markviss ráðgjöf/handleiðsla kennara og annars starfsfólks skóla í gagnreyndum aðferðum til að styðja við nám, hegðun og líðan barna og ungmenna (Eagle o.fl., 2014) sem nýtist öllum, sérstaklega nemendum með ADHD.

\section{Takmarkanir rannsóknar}

Niðurstöður pessarar rannsóknar ætti að túlka með gát vegna ýmissa takmarkana. Til dæmis var rannsóknin með pversniði og pví hvorki hægt að fullyrða neitt um orsakatengsl milli breyta né að munur milli hópa pátttakenda stafi raunverulega af misháum starfsaldri eða mismunandi skólastigum. Pátttökuhlutfall var nokkuð lágt (13\%) og ekki ljóst að hve miklu leyti úrtak rannsóknarinnar samsvarar hópi grunnskólakennara á Íslandi í heild. Gagnaöflun fór fram á háannatíma innan grunnskólanna (apríl-maí) og pví mögulegt að ákveðin valskekkja (e. selection bias) hafi átt sér stað, pað er að stærri og/eða fjölbreyttari hópur kennara hefði tekið pátt ef rannsóknin hefði farið fram á öðrum árstíma. Eins er ekki víst hversu mikið samræmi er á milli sjálfsmats pátttakenda til dæmis á eigin notkun stuðningsaðferða við kennslu nemenda með ADHD og raunverulegrar notkunar pátttakenda á pessum aðferðum. Par að auki voru pátttakendur ekki beðnir um að greina frá hversu oft peir nýttu hverja aðferð fyrir sig og pví getur verið að sumir pátttakendur sem merktu við ákveðna aðferð noti hana daglega meðan aðrir hafa ef til vill aðeins notað sömu aðferð í eitt skipti. Engu að sîður veittu niðurstöður pessarar rannsóknar áhugaverðar upplýsingar sem samræmast að ýmsu leyti niðurstöðum innlendra og erlendra rannsókna.

\section{Samantekt og næstu skref}

Íslenskir grunnskólakennarar sem tóku pátt í pessari rannsókn sögðust langflestir sækja pekkingu sína um ADHD til kennslu nemenda með röskunina, líkt og í fyrri rannsókn Jónínu Sæmundsdóttur (2009). Kennarar með lægri starfsaldur voru líklegri til að segjast sækja pekkingu sína um ADHD til kennaranáms en kennarar með lengri starfsaldur og seinni hópurinn virtist einnig meta sig verr undirbúinn til kennslu nemenda með ADHD eftir háskólanám en sá fyrrnefndi. Petta gæti verið vísbending um að kennaranám hafi breyst í pá átt að búa verðandi kennara betur undir starf með pessum nemendahópi, pótt petta purfi að rannsaka nánar. Meirihluti pátttakenda sagðist beita einhverjum stuðningsaðferðum byggðum á klínískum leiðbeiningum Embættis landlæknis með nemendum sínum með ADHD og flestir peirra sögðust meta breytingar í hegðun nemenda með einhverjum hætti, pó langoftast óformlega. Almennt virtust pátttakendur nokkuð vel að sér um gagnreynd 
úrræði vegna ADHD, miðað við algengustu svör peirra um pær aðferðir sem peir myndu helst mæla með við aðra í tengslum við ADHD.

Niðurstöður í heild bentu engu að síður til pess að ýmis tækifæri séu til aukinnar starfspróunar kennara á pessu sviði. Sérstaklega mikilvægt er að grunnskólakennarar fái ráðgjöf, handleiðslu og pjálfun í gagnreyndum stuðningsaðferðum fyrir nemendur með ADHD, einkum í markvissri notkun fjölbreyttrar hvatningar eins og með jákvæðri athygli, tíðu, lýsandi hrósi og/eða umbunar/ táknstyrkjakerfum. Að auki væri gagnlegt fyrir kennara að öðlast færni í notkun áreiðanlegra og réttmætra matsaðferða til að meta árangur og við að sníða stuðning betur að pörfum hvers og eins nemanda. Til viðbótar gæti verið hjálplegt að fræða kennara um önnur áhrifarík stuðningsúrræði, auk upplýsinga um aðferðir sem teljast gagnlitlar, til pess að gera peim betur kleift að meta gæði peirra fjöldamörgu úrræða sem í boði eru.

Gagnlegt væri ef næstu rannsóknir um petta efni beindust að áhrifum viðurkennds verklags, svo sem ráðgjafar, handleiðslu og stuðnings við kennara í gagnreyndum aðferðum við kennslu nemenda með ADHD. Áhugavert væri að fylgja pátttakendum eftir til lengri tíma, til dæmis yfir heilt skólaár eða lengur, og meta hversu mikil áhrif pessar aðferðir hafa bæði á kennara og nemendur. Æskilegt væri að pessar rannsóknir væru blandaðar og fylgdu annars vegar slembuðu rannsóknarsniði með samanburðarhópi (e. randomized controlled trial) svo hægt væri að álykta betur um orsakasamhengi milli veitts stuðnings og áhrifa hans á kennara og nemendur. Hins vegar væri gagnlegt að pær fælu einnig í sér eigindlegar rannsóknaraðferðir meðal starfsfólks skóla og nemenda, til pess að upplifun peirra og sýn komi eins skýrt fram og mögulegt er. Mikilvægt væri að inngrip og rannsóknir næðu einnig til foreldra en niðurstöður myndu hafa mikla pýðingu fyrir vettvang náms og menntunar og gera okkur kleift að gera öfluga skóla enn betri, par sem öll börn ættu að geta náð árangri og blómstrað.

\section{Icelandic primary and lower secondary school teacher knowledge and methods for supporting students with ADHD}

Effective prevention and intervention for children and youth with neurodevelopmental disorders, including attention-deficit hyperactivity disorder (ADHD), is crucial to supporting their positive development. School staff are often the primary agents of intervention for this group of students and it is important, therefore, that they be afforded opportunities and training in providing effective supports, based on best practices. The aim of the present study was to investigate Icelandic primary and lower secondary school teachers' sources of knowledge and perceived preparation regarding ADHD, their use of various support/instructional and progress monitoring practices for this group of students, and their perceptions of various aspects of their professional environment, in a sample of $N=592$ (88.5\% female) in-service elementary school teachers in Iceland, who taught at least one student with ADHD that school year. Participants were recruited via email sent to all members of the Association of Teachers in Primary and Lower Secondary Schools in Iceland and invited to participate in an online survey (13\% response rate). The study was approved by the National Bioethics Committee in Iceland (reference no. VSN19-070). Consistent with previous findings, results revealed that most participants (91\%) reported deriving knowledge about ADHD from their experience of teaching students with the disorder. Teaching experience was significantly associated with participants' self-reported level of preparation for supporting students with ADHD. Specifically, participants with greater teaching experience were more likely to report that their pre-service training (e.g., teacher education program) prepared them poorly for teaching students with ADHD, compared to participants with fewer years of teaching experience. This may suggest that in recent years, teacher education program development in Iceland has led to enhanced preparation of future teachers in working with students with ADHD, although more research is needed to better investigate this hypothesis. A majority of 
participants endorsed the use of certain effective strategies for supporting students with ADHD as well as informal progress monitoring methods. Participants also appeared to possess some knowledge concerning well-established ADHD treatment methods, including pharmacotherapy and psychotherapy. Approximately $20 \%$ of participants considered themselves to attend either "somewhat poorly" or "very poorly" to the needs of their students with ADHD, and a third of participants indicated they were "somewhat dissatisfied" or "very dissatisfied" with the professional support they received as part of working with this student population. Overall, results indicated that in-service teachers in Icelandic primary and lower secondary schools might benefit from increased professional development in this area. Behavioral consultation regarding evidence-based strategies (e.g., providing clear, explicit instruction, using descriptive praise and other forms of positive reinforcement) to support students with ADHD, as well as methods for progress monitoring may be particularly helpful in this regard. Supporting school staff in monitoring student progress using valid and reliable methods may also help increase the effectiveness of school-based interventions for students with the disorder, and better tailor supports to suit student needs. In addition to receiving training in applying well-established support strategies for ADHD in the classroom, offering school professionals information about the methods that do not show evidence supporting their effectiveness might also be helpful. Knowing both what works, as well as what is unlikely to work, may aid school staff in selecting the best interventions available and help save precious time and energy. Research examining the effectiveness of behavioral consultation for both teachers and students is needed, including whether and how potential effects of consultation unfold over time (e.g., across one or more school years). Ideally, future studies should comprise qualitative (e.g., interviews with school staff, students, and families) methods to capture the unique views and experiences of school community members, as well as quantitative (e.g., randomized, controlled trials) methods, to allow for stronger inferences concerning intervention effectiveness. Well-designed studies using mixed methods are highly informative for the field of education. Successful application of such findings is likely to help school staff, families, and ultimately students to thrive and flourish.

Key words: ADHD, attention-deficit hyperactivity disorder, teachers, evidence-based practice, student support

\section{Um höfunda}

Bergljót Gyða Guðmundsdóttir (bgg@hi.is) er sálfræðingur og dósent við Menntavísindasvið Háskóla Íslands.

Erla Karlsdóttir (karlsdottir.erla@gmail.com) er sálfræðingur og starfar í skólabjónustu hjá Pjónustumiðstöð Breiðholts á velferðarsviði Reykjavíkurborgar. Pessi rannsókn byggist á meistaraverkefni hennar í klínískri sálfræði við Háskólann í Reykjavík.

Margrét Sigmarsdóttir (margr@hi.is) er sálfræðingur með sérfræðiviðurkenningu í klínískri barnasálfræði og dósent við Menntavísindasvið Háskóla Íslands. 


\section{About the authors}

Bergljót Gyða Guðmundsdóttir (bgg@hi.is) is a psychologist and associate professor at the University of Iceland, School of Education.

Erla Karlsdóttir (karlsdottir.erla@gmail.com) is a school psychologist at Breidholt Service Center, Department of Welfare, City of Reykjavík. The current study is based on her master's thesis in clinical psychology at Reykjavík University.

Margrét Sigmarsdóttir (margr@hi.is) is a psychologist and a certified clinical child psychology specialist, and associate professor at the University of Iceland, School of Education.

\section{Heimildir}

American Psychiatric Association. (2013). Diagnostic and statistical manual of mental disorders (5. útgáfa).

Anastopoulos, A. D., DuPaul, G. J., Weyandt, L. L., Morrissey-Kane, E., Sommer, J. L., Rhoads, L. H., Murphy, K. R., Gormley, M. J. og Bergljót Gyða Guðmundsdóttir. (2018). Rates and patterns of comorbidity among first-year college students with ADHD. Journal of Clinical Child and Adolescent Psychology, 47(2), 236-247. https://doi.org/10.1080/15374416.2015.1105137

Anderson, D. L., Watt, S. E., Noble, W. og Shanley, D. C. (2012). Knowledge of attention deficit hyperactivity disorder (ADHD) and attitudes toward teaching children with ADHD: The role of teaching experience. Psychology in the Schools, 49(6), 511-525. https://doi.org/10.1002/pits.21617

Arcia, E., Frank, R., Sánchez-LaCay, A. og Fernández, M. C. (2000). Teacher understanding of ADHD as reflected in attributions and classroom strategies. Journal of Attention Disorders, 4(2), 91-101. https://doi. org/10.1177/108705470000400203

Barkley, R. A. (2014). Health problems and related impairments in children and adults with ADHD. Í R. A. Barkley (ritstjóri), Attention-deficit hyperactivity disorder: A handbook for diagnosis and treatment (4. útgáfa) (bls. 267-313). Guilford Press.

Bekle, B. (2004). Knowledge and attitudes about attention-deficit hyperactivity disorder (ADHD): A comparison between practicing teachers and undergraduate education students. Journal of Attention Disorders, 7, 151-161. https://doi.org/10.1177/108705470400700303

Bjørnebekk, G., Kjøbli, J. og Ogden, T. (2015). Children with conduct problems and co-occurring ADHD: Behavioral improvements following parent management training. Child \& Family Behavior Therapy, 37(1), 1-19. https://doi.org/10.1080/07317107.2015.1000227

Bowman-Perrott, L., Burke, M. D., Zaini, S., Zang, N. og Vannest, K. (2016). Promoting positive behavior using the Good Behavior Game: A meta-analysis of single-case research. Journal of Positive Behavior Interventions, 18(3), 180-190. https://doi.org/10.1177/1098300715592355

Canivez, G. L. (2019). Evidence-based assessment for school psychology: Research, training, and clinical practice. Contemporary School Psychology, 23, 194-200. https://doi.org/10.1007/s40688-019-00238-z

Catalá-López, F., Hutton, B., Núñez-Beltrán, A., Page, M. J., Ridao, M., Macías Saint-Gerons, D., Catalá, M. A., Tabarés-Seisdedos, R. og Moher, D. (2017). The pharmacological and non-pharmacological treatment of attention deficit hyperactivity disorder in children and adolescents: A systematic review with network meta-analyses of randomised trials. PloS One, 12(7), e0180355. https://doi.org/10.1371/journal.pone.0180355

Chronis, A. M., Chacko, A., Fabiano, G. A., Wymbs, B. T. og Pelham, W. E., Jr. (2004). Enhancements to the behavioral parent training paradigm for families of children with ADHD: Review and future directions. Clinical Child and Family Psychology Review, 7(1), 1-27. https://doi.org/10.1023/b:ccfp.0000020190.60808.a4

Connor, D. F. (2014). Stimulant and nonstimulant medications for childhood ADHD. Í R. A. Barkley (ritstjóri), Attention-deficit hyperactivity disorder: A handbook for diagnosis and treatment (4. útgáfa) (bls. 666-685). Guilford Press. 
Conroy, M. A., Sutherland, K. S., Algina, J. J., Wilson, R. E., Martinez, J. R. og Whalon, K. J. (2014). Measuring teacher implementation of the BEST in CLASS intervention program and corollary child outcomes. Journal of Emotional and Behavioral Disorders, 23(3), 144-155. https://doi.org/10.1177/1063426614532949

Cortese, S., Adamo, N., Del Giovane, C., Mohr-Jensen, C., Hayes, A. J., Carucci, S., Atkinson, L. Z., Tessari, L., Banaschewski, T., Coghill, D., Hollis, C., Simonoff, E., Zuddas, A., Barbui, C., Purgato, M., Steinhausen, H. C., Shokraneh, F., Xia, J. og Cipriani, A. (2018). Comparative efficacy and tolerability of medications for attention-deficit hyperactivity disorder in children, adolescents, and adults: A systematic review and network meta-analysis. The Lancet Psychiatry, 5(9), 727-738. https://doi.org/10.1016/S2215-0366(18)30269-4

Coulter, M. K. og Dean, M. E. (2007). Homeopathy for attention deficit/hyperactivity disorder or hyperkinetic disorder. The Cochrane Database of Systematic Reviews, (4), CD005648. https://doi.org/10.1002/14651858. CD005648.pub2

Curry, A. E., Yerys, B. E., Metzger, K. B., Carey, M. E. og Power, T. J. (2019). Traffic crashes, violations, and suspensions among young drivers with ADHD. Pediatrics, 143(6), e20182305. https://doi.org/10.1542/ peds.2018-2305

Danforth, J. S., Connor, D. F. og Doerfler, L. A. (2016). The development of comorbid conduct problems in children with ADHD: An example of an integrative developmental psychopathology perspective. Journal of Attention Disorders, 20(3), 214-229. https://doi.org/10.1177/1087054713517546

Deno, S. L. (2005). Problem-solving assessment. Í R. Brown-Chidsey (ritstjóri), Assessment for intervention: A problem-solving approach (bls. 10-40). Guilford Press.

Dicke, T., Parker, P. D., Marsh, H. W. og Kunter, M. (2014). Self-efficacy in classroom management, classroom disturbances, and emotional exhaustion: A moderated mediation analysis of teacher candidates. Journal of Educational Psychology, 106(2), 569-583. https://doi.org/10.1037/a0035504

Dort, M., Strelow, A. E., French, B., Groom, M., Luman, M., Thorell, L. B., Biele, G. og Christiansen, H. (2020). Bibliometric review: Classroom management in ADHD - is there a communication gap concerning knowledge between the scientific fields psychiatry/psychology and education? Sustainability, 12(17), 6826. https://doi.org/10.3390/su12176826

DuPaul, G. J., Chronis-Tuscano, A., Danielson, M. L. og Visser, S. N. (2019). Predictors of receipt of school services in a national sample of youth with ADHD. Journal of Attention Disorders, 23(11), 1303-1319. https://doi.org/10.1177/1087054718816169

DuPaul, G. J., Eckert, T. L. og Vilardo, B. (2012). The effects of school-based interventions for attention deficit hyperactivity disorder: A meta-analysis 1996-2010. School Psychology Review, 41(4), 387-412. https://doi. org/10.1080/02796015.2012.12087496

DuPaul, G. J., Evans, S. W., Mautone, J. A., Owens, J. S. og Power, T. J. (2020). Future directions for psychosocial interventions for children and adolescents with ADHD. Journal of Clinical Child and Adolescent Psychology, 49(1), 134-145. https://doi.org/10.1080/15374416.2019.1689825

DuPaul, G. J., Gormley, M. J., Anastopoulos, A. D., Weyandt, L. L., Labban, J., Sass, A. J., Busch, C. Z., Franklin, M. K. og Postler, K. B. (2021). Academic trajectories of college students with and without ADHD: Predictors of four-year outcomes. Journal of Clinical Child \& Adolescent Psychology. Fyrirfram rafræn birting. https://doi.org/10.1080/15374416.2020.1867990

DuPaul, G. J. og Langberg, J. M. (2014). Educational impairments in children with ADHD. Í R. A. Barkley (ritstjóri), Attention-deficit hyperactivity disorder: A handbook for diagnosis and treatment (4. útgáfa) (bls. 169-190). Guilford Press.

Eagle, J. W., Dowd-Eagle, S. E., Snyder, A. og Holtzman, E. G. (2014). Implementing a multi-tiered system of support (MTSS): Collaboration between school psychologists and administrators to promote systems-level change. Journal of Educational and Psychological Consultation, 25(2-3), 160-177. https://doi.org/10.1080/ 10474412.2014.929960

Erla Karlsdóttir. (2019). School-based treatment for ADHD, professional support and teacher burnout [meistararitgerð, Háskólinn í Reykjavík]. http://hdl.handle.net/1946/33566

Evans, S. W., Owens, J. S. og Bunford, N. (2014). Evidence-based psychosocial treatments for children and adolescents with attention-deficit/hyperactivity disorder. Journal of Clinical Child \& Adolescent Psychology, 43(4), 527-551. https://doi.org/10.1080/15374416.2013.850700 
Evans, S. W., Owens, J. S., Wymbs, B. T. og Ray, A. R. (2018). Evidence-based psychosocial treatments for children and adolescents with attention deficit/hyperactivity disorder. Journal of Clinical Child \& Adolescent Psychology, 47(2), 157-198. https://doi.org/10.1080/15374416.2017.1390757

Gísli Baldursson, Páll Magnússon, H. Magnús Haraldsson og Matthías Halldórsson. (2012). Vinnulag við greiningu og meðferð ADHD. https://www.landlaeknir.is/servlet/file/store93/item14259/ADHD-7.\%20 mars\%202012.pdf

Gormley, M. J., Sheridan, S. M., Dizona, P. J., Witte, A. L., Wheeler, L. A., Eastberg, S. R. A. og Cheng, K. C. (2020). Conjoint behavioral consultation for students exhibiting symptoms of ADHD: Effects at post-treatment and one-year follow-up. School Mental Health, 12, 53-66. https://doi.org/10.1007/s12310-019-09342-0

Guðrún Björg Ragnarsdóttir og Anna-Lind Pétursdóttir. (2013). „Uss, ég er að vinna!“ Áhrif einstaklingsmiðaðra stuðningsáætlana á námsástundun grunnskólanemenda með hegðunarerfiðleika. Netla-Veftímarit um uppeldi og menntun. https://skemman.is/bitstream/1946/17422/1/uss.pdf

Haraway, D. L. (2012). Monitoring students with ADHD within the RTI framework. The Behavior Analyst Today, 13(2), 17-21. https://doi.org/10.1037/h0100720

Hart, K. C., Fabiano, G. A., Evans, S. W., Manos, M. J., Hannah, J. N. og Vujnovic, R. K. (2017). Elementary and middle school teachers' self-reported use of positive behavioral supports for children with ADHD: A national survey. Journal of Emotional and Behavioral Disorders, 25(4), 246-256. https://doi. org/10.1177/1063426616681980

Jäkel, A. og von Hauenschild, P. (2012). A systematic review to evaluate the clinical benefits of craniosacral therapy. Complementary Therapies in Medicine, 20(6), 456-465. https://doi.org/10.1016/j.ctim.2012.07.009

Jerome, L., Gordon, M. og Hustler, P. (1994). A comparison of American and Canadian teachers' knowledge and attitudes toward attention deficit hyperactivity disorder (ADHD). The Canadian Journal of Psychiatry, 39, 563-567. https://doi.org/10.1177/070674379403900909

Jónína Sæmundsdóttir. (2009). Viðhorf kennara og reynsla af kennslu barna með ADHD. Netla - Veftimarit um uppeldi og menntun. https://skemman.is/bitstream/1946/13988/1/Vi\%c3\%b0horf\%20kennara.pdf

Kazdin, A. E. (2005). Parent management training: Treatment for oppositional, aggressive, and antisocial behavior in children and adolescents. Oxford University Press.

Kellam, S., Mackenzie, A., Brown, C. H., Poduska, J., Wang, W., Petras, H. og Wilcox, H. (2011). The Good Behavior Game and the future of prevention and treatment. Addiction Science and Clinical Practice, 6(1), 73-84.

Kofler, M. J., Harmon, S. L., Aduen, P. A., Day, T. N., Austin, K. E., Spiegel, J. A., Irwin, L. og Sarver, D. E. (2018). Neurocognitive and behavioral predictors of social problems in ADHD: A Bayesian framework. Neuropsychology, 32(3), 344-355. https://doi.org/10.1037/neu0000416

Korpershoek, H., Harms, T., de Boer, H., van Kuijk, M. og Doolaard, S. (2016). A meta-analysis of the effects of classroom management strategies and classroom management programs on students' academic, behavioral, emotional, and motivational outcomes. Review of Educational Research, 86(3), 643-680. https://doi. org/10.3102/0034654315626799

Kos, J., Richdale., A. og Jackson, M. (2004). Knowledge about attention-deficit/hyperactivity disorder: A comparison of in-service and pre-service teachers. Psychology in the Schools, 41(5), 517-526. https://doi. org/10.1002/pits. 10178

Kratochwill, T. R., Altschaefl, M. R. og Bice-Urbach, B. (2014). Best practices in school-based problem-solving consultation: Applications in prevention and intervention systems. Í P. L. Harrison og A. Thomas (ritstjórar), Best practices in school psychology: Data-based and collaborative decision making (bls. 461-482). National Association of School Psychologists.

Kuriyan, A. B., Pelham, W. E., Jr., Molina, B. S., Waschbusch, D. A., Gnagy, E. M., Sibley, M. H., Babinski, D. E., Walther, C., Cheong, J., Yu, J. og Kent, K. M. (2013). Young adult educational and vocational outcomes of children diagnosed with ADHD. Journal of Abnormal Child Psychology, 41(1), 27-41. https://doi. org/10.1007/s10802-012-9658-z

Lange, K. W., Hauser, J., Lange, K. M., Makulska-Gertruda, E., Nakamura, Y., Reissmann, A., Sakaue, Y., Takano, T. og Takeuchi, Y. (2017). The role of nutritional supplements in ADHD: What the evidence says. Current Psychiatry Reports, 19(2), 8. https://doi.org/10.1007/s11920-017-0762-1 
Lee, S. S., Lahey, B. B., Owens, E. B. og Hinshaw, S. P. (2008). Few preschool boys and girls with ADHD are well-adjusted during adolescence. Journal of Abnormal Child Psychology, 36(3), 373-383. https://doi. org/10.1007/s10802-007-9184-6

Madigan, D. J. og Kim, L. E. (2021). Does teacher burnout affect students? A systematic review of its association with academic achievement and student-reported outcomes. International Journal of Educational Research, 105, 101714. https://doi.org/10.1016/j.ijer.2020.101714

Margrét Sigmarsdóttir og Anna Björnsdóttir. (2012). Community implementation of PMTO ${ }^{\mathrm{TM}}$ : Impacts on specialist services and schools. Scandinavian Journal of Psychology, 53, 506-511. https://doi.org/10.1111/ j.1467-9450.2012.00974.x

Maslach, C. og Jackson, S. E. (1981). The measurement of experienced burnout. Journal of Occupational Behavior, 2(2), 99-113. https://doi.org/10.1002/job.4030020205

Molina, B., Howard, A. L., Swanson, J. M., Stehli, A., Mitchell, J. T., Kennedy, T. M., Epstein, J. N., Arnold, L. E., Hechtman, L., Vitiello, B. og Hoza, B. (2018). Substance use through adolescence into early adulthood after childhood-diagnosed ADHD: Findings from the MTA longitudinal study. Journal of Child Psychology and Psychiatry, and Allied Disciplines, 59(6), 692-702. https://doi.org/10.1111/jcpp.12855

Mulholland, S., Cumming, T. og Jung, J. (2015). Teacher attitudes towards students who exhibit ADHD type behaviours. Australasian Journal of Special Education, 39(1), 15-26. https://doi.org/10.1017/jse.2014.18

Murray, D. W., Molina, B. S. G., Glew, K., Houck, P., Greiner, A., Fong, D., Swanson, J., Arnold, L. E., Lerner, M., Hechtman, L., Abikoff, H. B. og Jensen, P. S. (2014). Prevalence and characteristics of school services for high school students with attention-deficit/hyperactivity disorder. School Mental Health, 6, 264-278. https://doi.org/10.1007/s12310-014-9128-6

Murray, D. W., Rabiner, D. L. og Hardy, K. K. (2011). Teacher management practices for first graders with attention problems. Journal of Attention Disorders, 15(8), 638-645. https://doi.org/10.1177/1087054710378234

Patterson, G. R., Forgatch, M. S. og DeGarmo, D. S. (2010). Cascading effects following intervention. Development \& Psychopathology, 22(4), 949-970. https://doi.org/10.1017/S0954579410000568

Pfiffner, L. J. og DuPaul, G. J. (2014). Treatment of ADHD in school settings. Í R. A. Barkley (ritstjóri), Attention-deficit hyperactivity disorder: A handbook for diagnosis and treatment (4. útgáfa) (bls. 596-629). Guilford Press.

Poznanski, B., Hart, K. C. og Cramer, E. (2018). Are teachers ready? Preservice teacher knowledge of classroom management and ADHD. School Mental Health, 10, 301-313. https://doi.org/10.1007/s12310-018-9259-2

Rains, L. A., Margrét Sigmarsdóttir og Forgatch, M. S. (2021). Development and implementation of an evidence-based parent management training intervention: Generation PMTO. Í M. E. Feinberg (ritstjóri), Designing evidence-based public health and prevention programs: Expert program developers explain the science and art (bls. 72-91). Routledge.

Reid, R., Vasa, S. F., Maag, J. W. og Wright, G. (1994). An analysis of teachers' perceptions of attention deficit-hyperactivity disorder. Journal of Research \& Development in Education, 27(3), 195-202.

Samband íslenskra sveitarfélaga og Félag grunnskólakennara. (2012). Sameiginleg könnun Sambands islenskra sveitarfélaga og Félags grunnskólakennara. Kynning á niðurstöðum. https://ssh.is/images/stories/Soknaraaetlun/ Kynning nidurstadna konnunar FG og samb loka 2012 08.pdf

Sarver, D. E., McCart, M. R., Sheidow, A. J. og Letourneau, E. J. (2014). ADHD and risky sexual behavior in adolescents: Conduct problems and substance use as mediators of risk. Journal of Child Psychology and Psychiatry, and Allied Disciplines, 55(12), 1345-1353. https://doi.org/10.1111/jcpp.12249

Sesselja Árnadóttir og Anna-Lind Pétursdóttir. (2013). „Ég get núna“: Upplifun nemenda af virknimati og einstaklingsmiðaðri stuðningsáætlun. Netla - Veftimarit um uppeldi og menntun. https://bit.ly/3ihCYm2

Sherman, J., Rasmussen, C. og Baydala, C. (2008). The impact of teacher factors on achievement and behavioural outcomes of children with attention deficit/hyperactivity disorder: A review of the literature. Educational Research, 50(4), 347-360. https://doi.org/10.1080/00131880802499803

Snæfríður Dröfn Björgvinsdóttir. (2014). Erfið hegðun nemenda: Viðhorfog vinnubrögð kennara [meistararitgerð, Háskóli Íslands]. http://hdl.handle.net/1946/17432

Snæfríður Dröfn Björgvinsdóttir og Anna-Lind Pétursdóttir. (2014). Erfið hegðun nemenda: Áhrif á líðan 
kennara. Uppeldi og menntun, 23(2), 65-86. https://ojs.hi.is/uppmennt/article/view/1934

Stoiber, K. C. (2014). A comprehensive framework for multitiered systems of support in school psychology. Í P. L. Harrison og A. Thomas (ritstjórar), Best practices in school psychology: Data-based and collaborative decision making (bls. 41-70). National Association of School Psychologists.

Sørlie, M.-A. og Ogden, T. (2015). School-wide positive behavior support-Norway: Impacts on problem behavior and classroom climate. International Journal of School \& Educational Psychology, 3(3), 202-217. https://doi.org/10.1080/21683603.2015.1060912

Thomas, R., Sanders, S., Doust, J., Beller, E. og Glasziou, P. (2015). Prevalence of attention-deficit/hyperactivity disorder: A systematic review and meta-analysis. Pediatrics, 135(4), e994-e1001. https://doi.org/10.1542/ peds.2014-3482

Uchida, M., Spencer, T. J., Faraone, S. V. og Biederman, J. (2018). Adult outcome of ADHD: An overview of results from the MGH longitudinal family studies of pediatrically and psychiatrically referred youth with and without ADHD of both sexes. Journal of Attention Disorders, 22(6), 523-534. https://doi. org/10.1177/1087054715604360

Uldall Torp, N. M. og Thomsen, P. H. (2020). The use of diet interventions to treat symptoms of ADHD in children and adolescents - a systematic review of randomized controlled trials. Nordic Journal of Psychiatry, 74(8), 558-568. https://doi.org/10.1080/08039488.2020.1769187

Urður Njarðvík. (2017). ADHD meðal barna og unglinga: Samsláttur við aðrar raskanir. Sálfreðiritið, 22, 7-18. https://www.hirsla.lsh.is/handle/2336/620536

Vysniauske, R., Verburgh, L., Oosterlaan, J. og Molendijk, M. L. (2020). The effects of physical exercise on functional outcomes in the treatment of ADHD: A meta-analysis. Journal of Attention Disorders, 24(5), 644-654. https://doi.org/10.1177/1087054715627489

Ward, R. J., Bristow, S. J., Kovshoff, H., Cortese, S. og Kreppner, J. (2020). The effects of ADHD teacher training programs on teachers and pupils: A systematic review and meta-analysis. Journal of Attention Disorders, 1087054720972801. Fyrirfram rafræn birting. https://doi.org/10.1177/1087054720972801

Wolraich, M. L., Hagan, J. F., Jr., Allan, C., Chan, E., Davison, D., Earls, M., Evans, S. W., Flinn, S. K., Froehlich, T., Frost, J., Holbrook, J. R., Lehmann, C. U., Lessin, H. R., Okechukwu, K., Pierce, K. L., Winner, J. D., Zurhellen, W. og Subcommittee on children and adolescents with attention-deficit/hyperactive disorder. (2019). Clinical practice guideline for the diagnosis, evaluation, and treatment of attention-deficit/ hyperactivity disorder in children and adolescents. Pediatrics, 144(4), e20192528. https://doi.org/10.1542/ peds.2019-2528

Bergljót Gyða Guðmundsdóttir, Erla Karlsdóttir og Margrét Sigmarsdóttir. (2021).

Pekking og aðferðir grunnskólakennara á Íslandi í stuðningi við nemendur með ADHD

Netla - Veftímarit um uppeldi og menntun. Menntavísindasvið Háskóla Íslands.

Sótt af https://netla.hi.is/greinar/2021/alm/10.pdf

DOI: https://doi.org/10.24270/netla.2021.10 